九州大学学術情報リポジトリ

Kyushu University Institutional Repository

The Genus Andrena from Kazakhstan and Kyrgyzstan Collected by the Kyushu University Expedition (Hymenoptera, Andrenidae) (1)

Tadauchi, 0samu

Entomological Laboratory, Faculty of Agriculture, Kyushu University, Fukuoka

https://doi.org/10.5109/2853

出版情報 : ESAKIA. 46，pp.1-19，2006-06-30. Entomological Laboratory，Faculty of Agriculture， Kyushu University

バージョン：

権利関係 : 


\title{
The Genus Andrena from Kazakhstan and Kyrgyzstan Collected by the Kyushu University Expedition (Hymenoptera, Andrenidae) (1)
}

\author{
Osamu TADAUCHI \\ Entomological Laboratory, Faculty of Agriculture, Kyushu University, Fukuoka, \\ 812-8581 Japan
}

\begin{abstract}
We conducted five surveys in Kazakhstan, Kyrgyzstan and northwestern China from 2000 to 2004 in order to study wild bee fauna and pollination biology for combating desertification and planting campaigns in Asian arid areas. This is the first report of a taxonomic study of the genus Andrena collected by the Kyushu University Expedition in Kazakhstan and Kyrgyzstan. In this paper ten species of the genus Andrena from Kazakhstan are recorded for the first time.
\end{abstract}

Key words: Taxonomy, Hymenoptera, Andrenidae, Andrena, Kazakhstan, Kyrgyzstan.

\section{Introductoion}

The young Russian explorer Fedtchenko (1844-1873) made three explorations from 1869 to 1873 of Central Asia, now Uzbekistan east of Samarkand, Tadzhikistan, west of Kyrgyzstan and south of Kazakhstan, and brought huge insect collections to St. Petersburg, Russia. Morawitz, one of founders of the Russian Entomological Society, studied Fedtchenko's bee collection and recorded 438 species belonging to 36 genera from Central Asia in 1876. He recorded 68 species of the genus Andrena, of which 17 species were common with Europe in distribution and 51 were new species. Some investigators studied species of Andrena in Central Asia, such as Radoszkowski (1867, 1886, 1893), Morawitz (1866, 1888, 1894, 1895), Viereck (1916, 1918), Friese (1922), Lebedev (1929, 1932, 1933), Cockerell (1906a, 1906b, 1930), Popov (1940, 1949, 1952, 1958, 1967), Warncke (1967), Osytshnjuk (1977, 1979, 1982a, 1982b, 1983a, 1983b, 1984, 1985, 1986, 1993, 1994, 1995), Schönitzer (1997) and Xu and Tadauchi (1997). However, most of the species were sporadically recorded and no revisional study was found, except for several subgenera of the genus. Gusenleitner and Schwarz (2000, 2001, 2002) published taxonomic comments on the Andrena species described by Osytshnjuk and Morawitz, which were useful for the study of Central Asian species.

We conducted five surveys in Kazakhstan, Kyr- gyzstan and northwestern China from 2000 to 2004 in order to study wild bee fauna and pollination biology for combating desertification and planting campaigns in Asian arid areas. We collected many bee specimens in the field surveys. I then examined nearly all of the type specimens of the genus Andrena described by Morawitz and some of those presented by Osytshnjuk, and in 2005 compared our new collection with the types in St. Petersburg. As Fedtchenko's expedition was conducted mainly in Uzbekistan, many species were described from this region of Asia. The bee fauna of Kazakhstan has not been well studied until now. The Andrena fauna of Central Asia is known to be more or less related to the European fauna. On the other hand, little information exists on the relationships between fauna of Central Asia and East Asia. This is the first report of a taxonomic study of the genus Andrena collected by the Kyushu University Expedition in Kazakhstan and Kyrgyzstan, partly including collection of the Zoological Institute of Kazakhstan. In this paper ten species of the genus Andrena from Kazakhstan are recorded for the first time. Collections of Andrena specimens obtained from Central Asia and borrowed from Oberösterreichischen Landesuseum, Linz and the American Museum of Natural History, New York will be also analyzed in the near future. The morphological terms used in descriptions followed Tadauchi and $\mathrm{Xu}$ (1995).

E-mail: tadauchi@agr.kyushu-u.ac.jp 


\section{O. TADAUCHI}

\section{Andrena (Leimelissa) bairacumensis Morawitz}

(Fig. 1: A-F)

Andrena bairacumensis Morawitz, 1876, in Fedtschenko, Izv. Imp. Obschch. Ljubit. Estest. Antrop. Etnog.: 170 [female, Uzbekistan], Osytshnjuk, 1984, Taxonomy \& Zoogeography of Insects, Kiev: 20.

Andrena (Leimelissa) bairacumensis: Gusenleitner \& Schwarz, 2001, Entomofauna, 22: 102, Gusenleitner \& Schwarz, 2002, Entomofauna, Suupl., 12: 110-112.

\section{Redescription.}

Female: BL 11.1mm, WL $8.6 \mathrm{~mm}(\mathrm{n}=1)$.

Color: Flagellum brownish beneath; mandible with apical half reddened; wing membranes subhyaline, moderately brown, veins and pterostigma brownish; tibial spurs reddish brown; posterior depressions of metasomal terga reddish yellow.
Pubescence: Hairs on head sparse except antennal area, whitish; those on clypeus $100 \mu \mathrm{m}$, with lateral fringes, dense; those on vertex 200-250 $\mu \mathrm{m}$, without brownish; those on genal area $200-400 \mu \mathrm{m}$, dense; facial fovea white. Hairs on mesoscutum $100 \mu \mathrm{m}$, short, dense, white, velutinous, not intermixed with brownish; those on scutellum 100-120 $\mu \mathrm{m}$; those on mesepisternum 300-400 $\mu \mathrm{m}$; propodeal corbicula well developed, internal area without simple hairs, without anterior fringes; trochanteral floccus imperfect, dense, whitish; femoral floccus dense; tibial scopal hairs long, simple, white. Hairs on metasomal terga 1-2 scanty; those on terga 3-4 rather short, pale brown; terga 1-4 with dense, white hair bands, broadly interrupted on terga 1-3, completed on tergum 4; caudal fimbria pale brownish; sterna 2-5 with long, sparse, pale brownish subapical fimbriae.

Structure: Head: HL/HW = 0.91. HW: MsW: MtW $=3.2: 3.4: 3.4$. Vertex flat, very narrow, shagreened

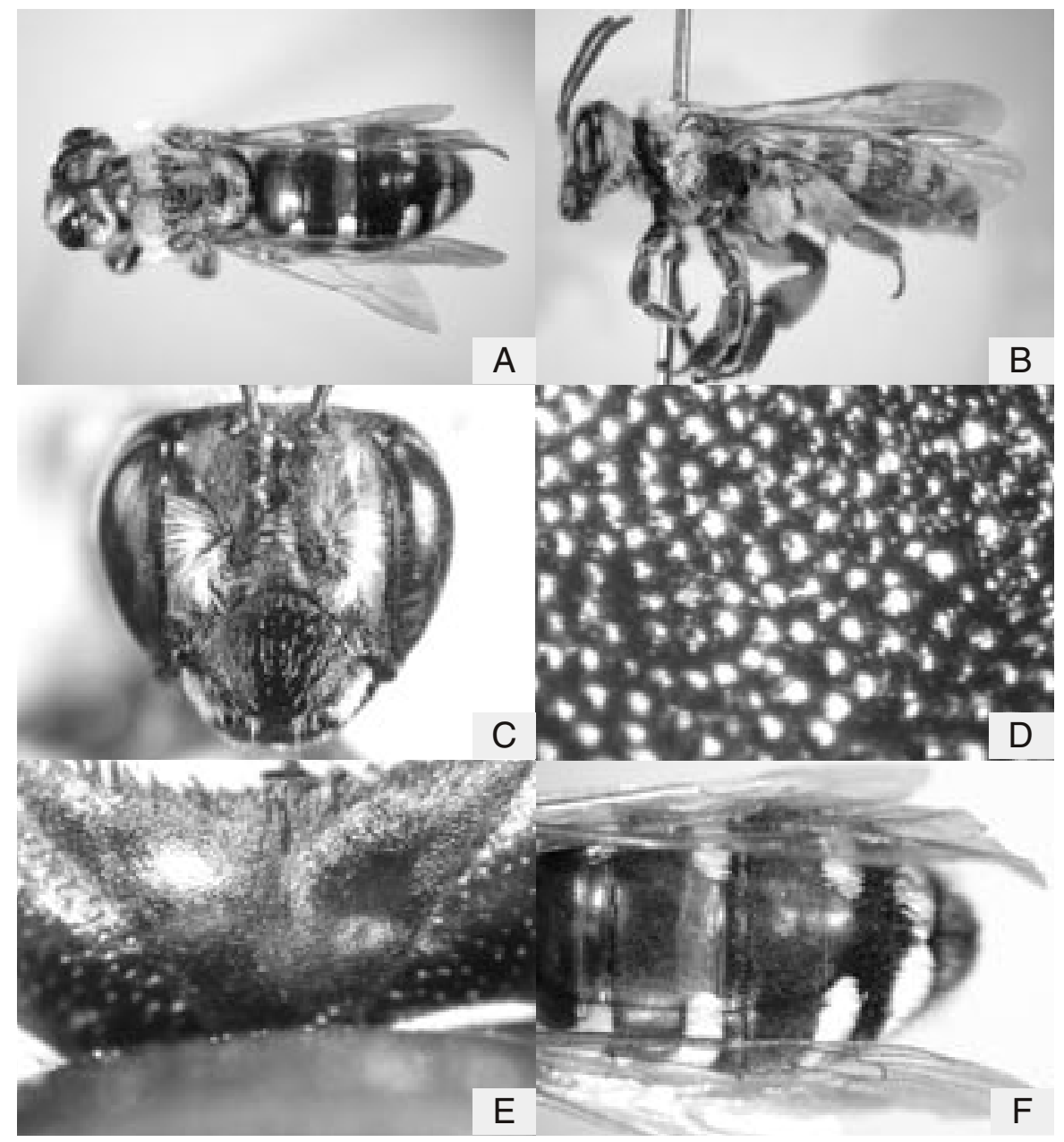

Fig. 1: A-F. Andrena (Leimelissa) bairacumensis Morawitz, female. A: general habitus in dorsal view; B: the same in lateral view; C: head in frontal view; D: mesoscutum; E: propodeum; F: metasomal terga. 
with obscure PP. OOD: POD: $O C D=1.2: 0.9: 0.2$. FL1 $>$ FL2+3, FL2 $>$ FL3 which are as broad as long. Eyes with inner margins paralleled. Facial fovea occupying $1 / 2$ space between eye and lateral ocellus, much extending to a line at lower margins of antennal fossae, $\mathrm{FVL}=$ $1.7 \mathrm{~mm}, \mathrm{FVW}=0.3 \mathrm{~mm}$. Supraclypeal area falt, weakly tessellate and shiny with small PP. Face above antennal fossae with fine longitudinal rugulae and weak interrugal PP, shagreening surface. Facial quadrangle longer than broad (2.0: 2.5). Clypeus flat, surface very densely tessellate with sparse, obscure, small PPø20-30 $\mu \mathrm{m}$, IS $=1-4$, without longitudinal median impunctate space, $\mathrm{CPL}=1.2 \mathrm{~mm}$. Process of labrum very large, semicircular, slightly emarginate medially. Lower paraocular area very weakly tessellate and shiny with minute, shallow PP, IS $<0.5$. Malar space linear. Genal area broader than eye, GW: $\mathrm{EW}=0.7$ : 0.6, surface finely tessellate with minute PP near eye. Mesosoma: Pronotum without lateral suture and humeral angle, surface weakly tessellate and shiny with minute PP. Mesoscutum smooth and shiny with distinct, small PРø20 $\mu \mathrm{m}, \mathrm{IS}=1-2$. Scutellum very weakly tessellate with small PP. Propodeal enclosure very large, rugulose at basal $1 / 5$, very weakly tessellate apically; dorsal face of propodeum smooth and shiny with small PP. Mesepisternum weakly tessellate with small PP. Vein 1st $m$-cu meeting second submarginal cell at middle of cell. Metasoma: Metasomal terga very weakly tessellate and shiny with dense, small PP $\varnothing 20 \mu \mathrm{m}, \mathrm{IS}=1-2$; posterior depressions of terga weakly indicated; pygidial plate $\mathrm{V}$-shaped, large, internal area with raised triangular area. Sterna 2-5 weakly tessellate and shiny with dense, minute PP.

Specimens examined. [KAZAKHSTAN] 1 female, Togusken, semi-desert near Janatas, S. Kazakhstan Prov., 7. vi. 2003 (O. Tadauchi).

Remarks. This species is somewhat similar to Andrena beijingensis $\mathrm{Xu}$ from eastern Asia, but the female can be separated from that of beijingensis by the metasomal terga 1-4 with dense, white hair bands, the process of labrum slightly emarginate medially, and the dorsal face of propodeum smooth and shiny with small PP.

Distribution. Uzbekistan, Kazakhstan (new record).

Floral record. Not available.

\section{Andrena (Simandrena) quadrifasciata Morawitz} (Fig. 2: A-F)

Andrena quadrifasciata Morawitz, 1876, in Fedtschenko, Izv. Imp. Obschch. Ljubit. Estest. Antrop. Etnog.: 168 [female, Tadzhikistan].

Andrena quadrifasciatula Viereck, 1918, Proc. Biol.
Soc. Wash., 31: 59 [new name for Andrena quadrifasciata Morawitz, 1876, nec quadrifasciata Gmelin, 1790]

Andrena (Simandrena) quadrifasciata: Gusenleitner \& Schwarz, 2001, Entomofauna, 22: 157, Gusenleitner \& Schwarz, 2002, Entomofauna, Suupl., 12: 623-624.

\section{Redescription.}

Female: BL $10.0 \mathrm{~mm}$, WL $7.3 \mathrm{~mm}(\mathrm{n}=1)$.

Color: Flagellum brownish beneath; mandible with apical half reddened; wing membranes subhyaline, pale brown, veins and pterostigma yellowish brown; tibial spurs yellow; posterior depressions of metasomal terga yellowish brown.

Pubescence: Hairs on head and thorax moderately dense, whitish; those on clypeus $200 \mu \mathrm{m}$; those on vertex $400 \mu \mathrm{m}$, without brown; those on genal area 200-300 $\mu \mathrm{m}$; facial fovea pale brownish above, whitish below. Hairs on mesoscutum $300-400 \mu \mathrm{m}$, white, not intermixed with brownish; those on scutellum 500-600 $\mu \mathrm{m}$; those on mesepisternum $400-500 \mu \mathrm{m}$; propodeal corbicula moderately developed, internal area with short, sparse simple hairs; trochanteral floccus imperfect, sparse, whitish; femoral floccus dense; tibial scopal hairs long, simple, white. Hairs on metasomal terga 1 white, suberect, long, sparse; those on terga 3-4 rather short, brown; terga 1-4 with dense, white hair bands, broadly interrupted on terga 1-2, completed on terga 3-4; caudal fimbria brownish white; sterna 2-5 with long, sparse, whitish subapical fimbriae.

Structure: Head: HL/HW = 0.74. HW: MsW: MtW =3.1: 2.8: 3.0. Vertex round, weakly tessellate with obscure PP. OOD: POD: $O C D=1.3: 0.9: 0.4$. FL1 < FL2+3, FL2 = FL3 which are as broad as long. Eyes with inner margins subparalleled. Facial fovea occupying $1 / 2$ space between eye and lateral ocellus, attaining to a line at lower margins of antennal fossae, $\mathrm{FVL}=$ $1.3 \mathrm{~mm}, \mathrm{FVW}=0.3 \mathrm{~mm}$. Supraclypeal area shagreened with roughened PP. Face above antennal fossae with fine longitudinal rugulae and weak interrugal PP, shagreening surface. Facial quadrangle slightly broader than long (2.1: 2.0). Clypeus weakly convex, surface very weakly tessellate and shiny with distinct PPø20-30 $\mu \mathrm{m}$, IS $<0.5$, without longitudinal median impunctate space, $\mathrm{CPL}=0.9 \mathrm{~mm}$. Process of labrum shiny, rectangular, not emarginated medially. Lower paraocular area smooth and shiny with minute, shallow PP, IS $<0.5$. Malar space linear. Genal area broader than eye, GW: $\mathrm{EW}=0.7: 0.5$, surface broadly shiny and smooth with minute PP near eye. Mesosoma: Pronotum with lateral suture and without humeral angle, surface smooth and 


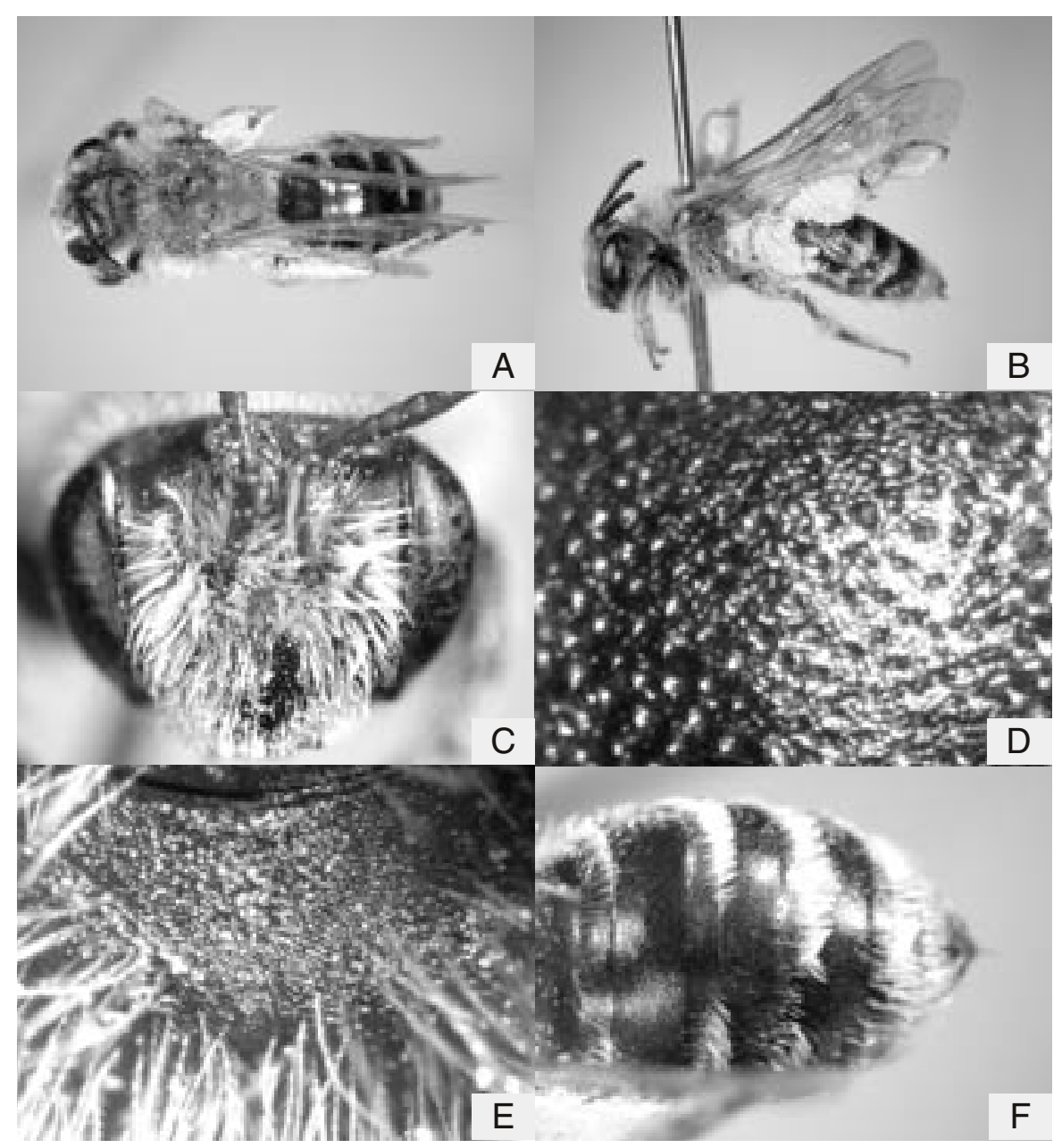

Fig. 2: A-F. Andrena (Simandrena) quadrifasciata Morawitz, female. A: general habitus in dorsal view; B: the same in lateral view; C: head in frontal view; D: mesoscutum; E: propodeum; F: metasomal terga.

shiny with minute PP. Mesoscutum weakly tessellate with small PРø20 $\mu \mathrm{m}, \mathrm{IS}=1$. Scutellum weakly tessellate with small PP. Propodeal enclosure shagreened basally, densely tessellate apically; dorsal face of propodeum shagreened with roughened PP. Mesepisternum weakly tessellate and shiny with a little roughened PP. Vein 1st $m$-cu meeting second submarginal cell at middle of cell. Metasoma: Metasomal terga weakly tessellate and shiny with obscure, small PPø20 $\mu \mathrm{m}$, IS =1-3; posterior depressions of terga weakly indicated; pygidial plate $\mathrm{V}$-shaped, internal area with raised triangular area. Sterna 2-5 weakly tessellate and shiny with minute PP.

Specimens examined. [KAZAKHSTAN] 1 female, Moyenkum-Chu, Jambul Prov., 17. v. 2004 (R. Murao).

Remarks. This species is somewhat similar to Andrena yamato Tadauchi et Hirashima from eastern Asia, but the female can be separated from that of yamato by the propodeal enclosure not rugosed but shagreened basally, densely tessellate apically, and the propodeal corbicula not perfectly developed with internal simple hairs. This species may be placed in the different subgenus in future study.

Distribution. Tadzhikistan, Kazakhstan (new record).

Floral record. Not available.

\section{Andrena (Melandrena) infirma Morawitz}

(Fig. 3: A-F)

Andrena infirma Morawitz, 1876, in Fedtschenko, Izv. Imp. Obschch. Ljubit. Estest. Antrop. Etnog.: 195 [female \& male, Uzbekistan].

Andrena (Melandrena) infirma: Gusenleitner \& Schwarz, 2001, Entomofauna, 22: 131, Gusenleitner \& Schwarz, 2002, Entomofauna, Suppl., 12: 366-367.

Redescription.

Female: BL 15.4-16.3 mm, WL 12.8-13.4 mm (n=5). 
Color: Flagellum reddish brown beneath; mandible with apical third reddened; wing membranes subhyaline, moderately brown, veins and pterostigma brown; tibial spurs reddish yellow; posterior depressions of metasomal terga yellowish brown.

Pubescence: Hairs on head dense, black and thorax

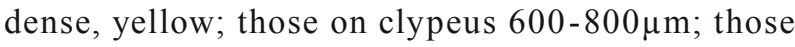
on vertex $600-900 \mu \mathrm{m}$; those on genal area $800-1000$ $\mu \mathrm{m}$; facial fovea black. Hairs on mesoscutum 600-800 $\mu \mathrm{m}$, not intermixed with brownish; those on scutellum $800-1000 \mu \mathrm{m}$; those on mesepisternum 800-1200 $\mu \mathrm{m}$, yellowish above, brownish below; propodeal corbicula moderately developed, internal area with long, sparse simple hairs, with anterior fringes; trochanteral floccus imperfect, sparse, yellow; femoral floccus dense; tibial scopal hairs long, simple, black. Hairs on metasomal terga long; those on tergum 1 yellowish; those on terga 2-4 black; terga 2-4 without white hair bands; caudal fimbria black; sterna 2-5 with long, sparse, black subapical fimbriae.

Structure: Head: HL/HW = 0.85. HW: MsW: MtW $=4.5: 5.0: 5.0$. Vertex flat in frontal view, shagreened with roughened PP. OOD: POD: $O C D=1.9$ : 1.1: 1.0. $\mathrm{FL} 1=\mathrm{FL} 2+3, \mathrm{FL} 2=\mathrm{FL} 3$ which are as broad as long. Eyes with inner margins paralleled. Facial fovea broad and long, occupying full space between eye and lateral ocellus above, extending to below a line at lower margins of antennal fossae, $\mathrm{FVL}=2.4 \mathrm{~mm}, \mathrm{FVW}=$ $0.6 \mathrm{~mm}$. Supraclypeal area shagreened with roughened PP. Face above antennal fossae with fine longitudinal rugulae and weak interrugal $\mathrm{PP}$, shagreening surface. Facial quadrangle broader than long (3.4: 3.2). Clypeus strongly convex, surface smooth and shiny with dense, distinct PPø40 $\mu \mathrm{m}$, IS $<0.5$, with narrow longitudinal median impunctate space, $\mathrm{CPL}=1.7 \mathrm{~mm}$. Process of labrum large, trapezoidal, narrow apically. Lower para-

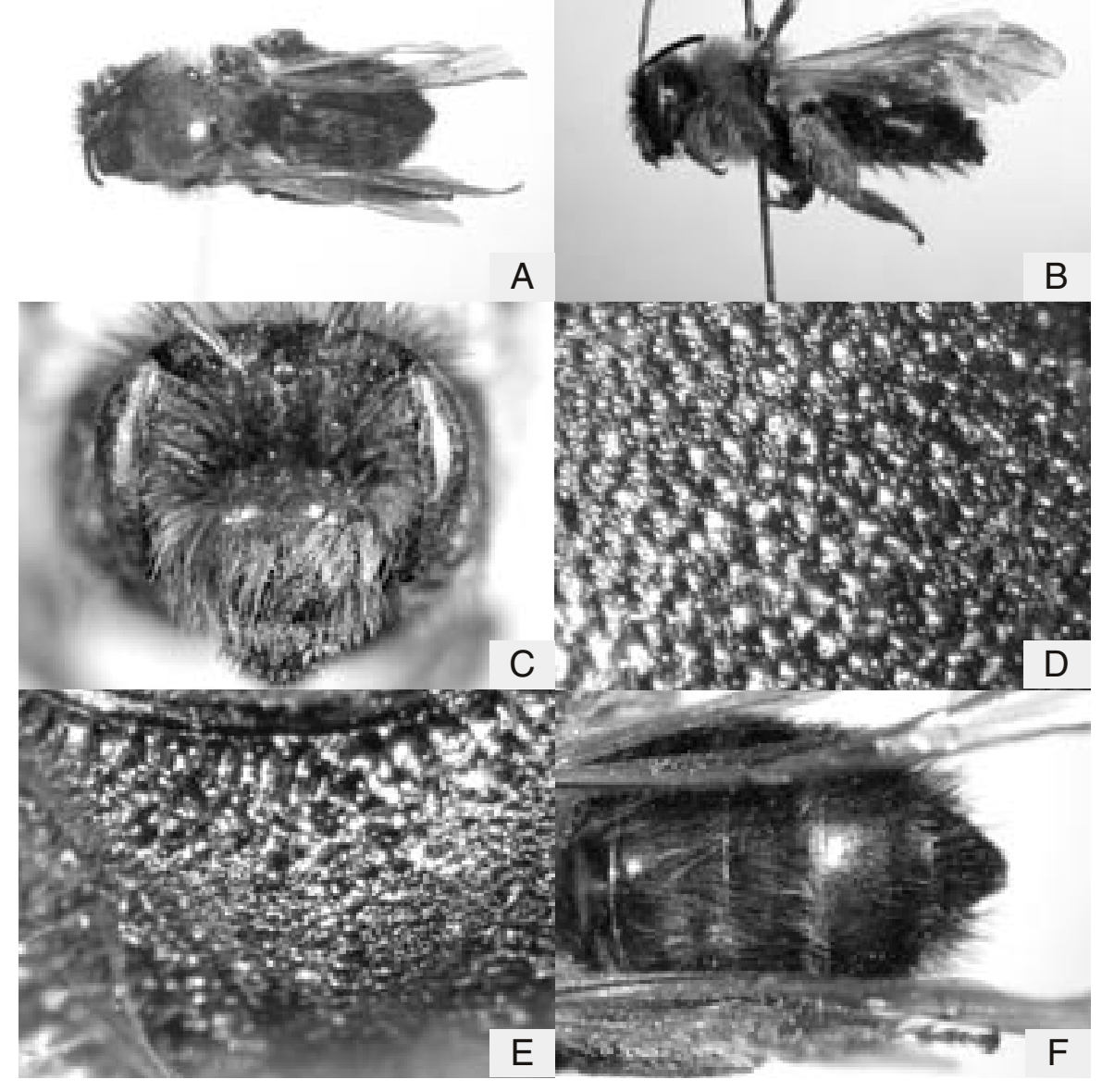

Fig. 3: A-F. Andrena (Melandrena) infirma Morawitz, female. A: general habitus in dorsal view; B: the same in lateral view; C: head in frontal view; D: mesoscutum; E: propodeum; F: metasomal terga. 


\section{O. TADAUCHI}

ocular area smooth and shiny with minute PP, IS $<0.5$. Malar space moderately broad, $1 / 3$ of basal width of mandible . Genal area broader than eye, $\mathrm{GW}$ : $\mathrm{EW}=1.2$ : 0.7 , surface broadly smooth and shiny with minute PP near eye. Mesosoma: Pronotum with lateral suture and without humeral angle, surface weakly tessellate with minute PP. Mesoscutum densely tessellate with dense, shallow PPø40 $\mu \mathrm{m}, \mathrm{IS}<0.5$. Scutellum densely tessellate with dense, small PP. Propodeal enclosure rugulose at basal $1 / 2$, finely tessellate apically; dorsal face of propodeum shagreened with roughened PP. Mesepisternum densely tessellate, a little roughened with obscure PP. Vein 1st $m$-cu meeting second submarginal cell at middle of cell. Metasoma: Metasomal terga smooth and shiny with small PPø40 $\mu \mathrm{m}$, tergum 1 sparser, IS = $1-3$, terga 2-4 denser, IS $=0.5-1$; posterior depressions of terga not well indicated; pygidial plate V-shaped, internal area with weak raised triangular area. Sterna 2-5 weakly tessellate and shiny with minute PP.

Specimens examined. [KAZAKHSTAN] Achisai, 670-700m, Mts. Karatau, S. Kazakhstan Prov.: 1 female, 4. vi. 2003 (O. Tadauchi); 1 female, 5. vi. 2003 (O. Tadauchi); 1 female, 5. vi. 2003 (K. Mitai); 1 female, Jabagly 1150-1250m, S. Kazakhstan Prov., 3. v. 2004 (V. Linda); 1 female, Jabagly 1180-1250m, S. Kazakhstan Prov., 11. v. 2004 (R. Murao).

Remarks. This species is similar to Andrena parathoracica Hirashima from eastern Asia, but the female can be separated from that of parathoracica by the metasomal terga with abundant long black hairs, the clypeus with longitudinal impunctate line and the pronotum without notch at subapical margin.

Distribution. Uzbekistan, Kazakhstan (new record).

Floral record. Ferula tenuisecta.

\section{Andrena (Campylogaster) incisa Eversmann} (Fig. 4: A-F)

Andrena incisa Eversmann, 1852, Bull. Soc. Nat. Moscou, 25: 24 [female, European Russia]; Morawitz, 1866, 13; Morawitz, 1876: 172; Morawitz, 1894: 70; Frey-Gessner, 1906: 324; Dylewska, 1987, Acta Zool. Cracov., 30: 451; Dylewska, 2000, Keys Ident. Pol. Insects, XXIV Hymenoptera, Andrenidae: 49; Schmid-Egger \& Scheuchl, 1997: Ill. Bestim. Wildbienen Deut. Österreichs Bd. III: Andrenidae: 69.

Andrena (Campylogaster) incisa: Osytshnjuk, 1977,

Fauna Ukraini 12 (5): 172; Osytshnjuk, 1978,

Opered. Faune SSSR, 119: 315, 345; Gusenleitner \&

Schwarz, 2002, Entomofauna, Suupl., 12: 363-364.

Andrena gracilis Eversmann, 1852 (nec Andrena graci- lis Schenck, 1869), Bull. Soc. Nat. Moscou, 25: 25

[female \& male, European Russia].

\section{Redescription.}

Female: BL $13.0 \mathrm{~mm}$, WL $9.2 \mathrm{~mm}(\mathrm{n}=1)$.

Color: Flagellum reddish brown beneath; mandible with apical half reddened; wing membranes subhyaline, moderately pale brownish, veins and pterostigma brown; tibial spurs reddish yellow; posterior depressions of metasomal terga reddish brown.

Pubescence: Hairs on head and thorax dense, yellowish to fulvous; those on clypeus pale yellow, $300-400 \mu \mathrm{m}$, densely covering the surface; those on vertex yellow without brown or black, 400-600 $\mu \mathrm{m}$; those on genal area $400-500 \mu \mathrm{m}$; facial fovea bright yellow above paler below. Hairs on mesoscutum 400-500 $\mu \mathrm{m}$, reddish yellow, dense; those on scutellum 400-600 $\mu \mathrm{m}$; those on mesepisternum 400-600 $\mu \mathrm{m}$, yellowish; propodeal corbicula moderately developed, internal area with long, sparse simple hairs; trochanteral floccus imperfect, sparse, whitish; femoral floccus dense; tibial scopal hairs long, simple, whitish. Hairs on metasomal terga 1-2 scanty; those on terga 3-4, appressed yellowish brown; terga 1-4 with dense broad yellowish bands, broadly interrupted on terga 1-2, completed on terga 3-4; caudal fimbria golden; sterna 2-5 with long, yellowish subapical fimbriae.

Structure: Head: HL/HW = 0.82. HW: MsW: MtW = 3.9: $3.4: 4.3$. Vertex broad and round in frontal view, shiny with dense PP, not shagreened. OOD: POD: OCD = 1.6: 1.0: 1.1. FL1 = FL2+3, FL2 > FL3 which are broader than long. Eyes with inner margins subparalleled. Facial fovea broad above, occupying full space between eye and lateral ocellus, extending to below a line at lower margins of antennal fossae, FVL $=1.6$ $\mathrm{mm}, \mathrm{FVW}=0.5 \mathrm{~mm}$. Supraclypeal area with dense PP. Face above antennal fossae with fine longitudinal rugulae and weak interrugal PP, shagreening surface. Facial quadrangle quadrate (2.6: 2.6). Clypeus moderately convex, surface smooth and weakly shiny with PРø20 $\mu \mathrm{m}$, IS $=0.5$, without longitudinal median impunctate space, $\mathrm{CPL}=1.2 \mathrm{~mm}$. Process of labrum large, trapezoidal, weakly emarginate medially. Lower paraocular area smooth and shiny with minute PPø20 $\mu \mathrm{m}, \mathrm{IS}=0.5$. Malar space linear. Genal area broader than eye, GW: $\mathrm{EW}=1.0$ : 0.7 , surface broadly shiny with minute PP near eye. Mesosoma: Pronotum with humeral angle and lateral suture, surface weakly tessellate with minute PP above, polished below. Mesoscutum polished and shiny with PРø20 $\mu \mathrm{m}, \mathrm{IS}=1-2$. Scutellum polished and shiny with scattered minute PP. Propodeal enclosure rugulose 


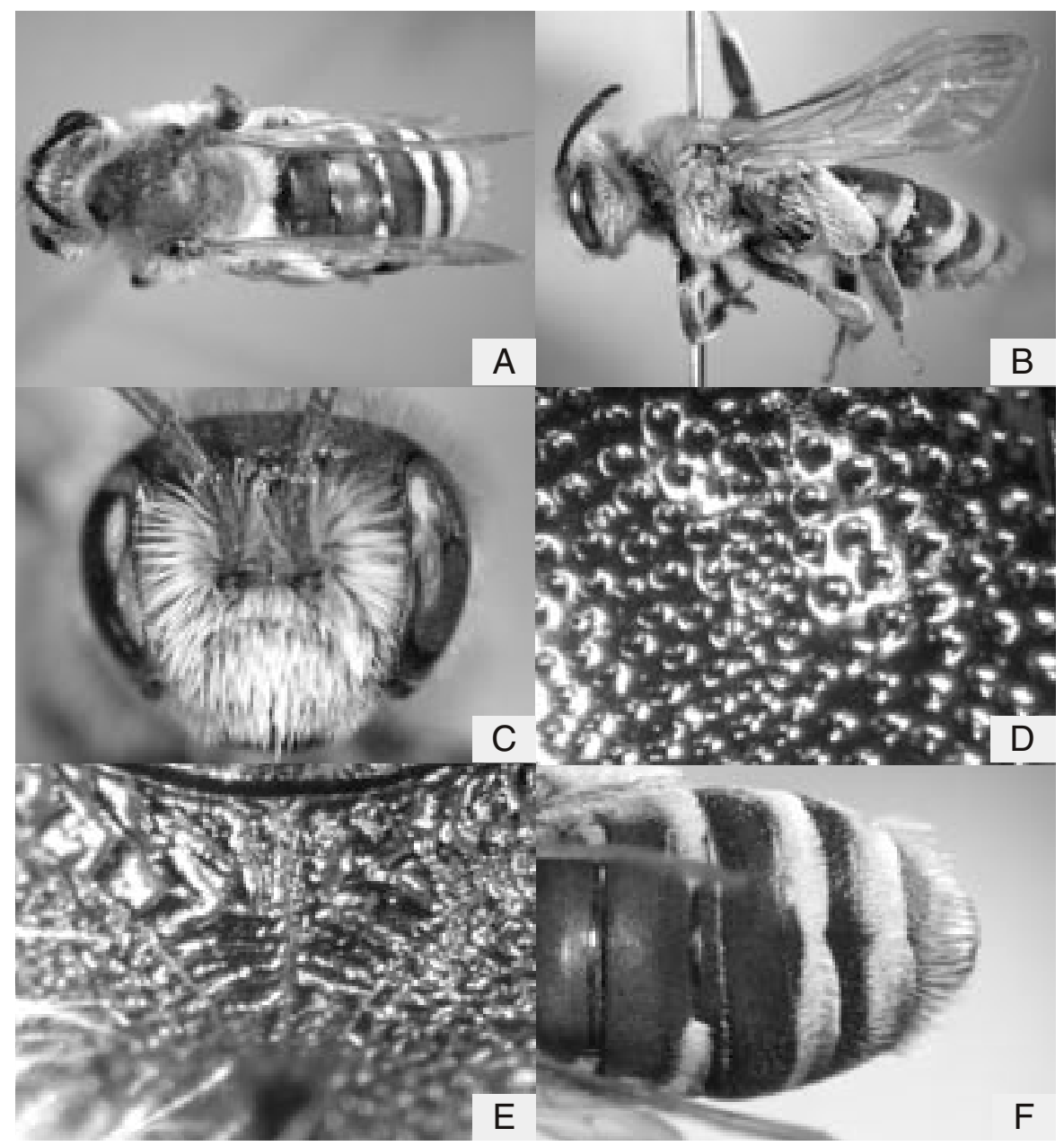

Fig. 4: A-F. Andrena (Campylogaster) incisa Eversmann, female. A: general habitus in dorsal view; B: the same in lateral view; C: head in frontal view; D: mesoscutum; E: propodeum; F: metasomal terga.

all over; dorsal face of propodeum shagreened with roughened PP. Mesepisternum smooth and wekly shiny with distinct PP. Vein 1st $m$-cu meeting second submarginal cell at middle of cell. Metasoma: Metasomal terga smooth and shiny with distinct dense PРø20 $\mu \mathrm{m}$, IS $<0.5$; posterior depressions of terga well indicated; pygidial plate U-shaped, internal area with weak raised triangular area. Sterna 2-5 densely tessellate with obscure dense PP.

Specimens examined. [KAZAKHSTAN] 1 female, Achisai 670-700m, Mts. Karatau, S. Kazakhstan Prov., 5. vi. 2003 (K. Mitai).

Remarks. This species is somewhat similar to Andrena chengtehensis Yasumatsu in eastern Asia, but the female can be separated from that of chengtehensis by the process of labrum large and trapezoidal, the mesoscutum with long dense yellow to fulvous hairs, the metasomal terga 1-4 with dense broad yellowish hair bands.

Distribution. Greece, Turkey, East Europe, Kauka- sus, Kazakhstan (new record).

Floral record. Ferula tenuisecta.

\section{Andrena (Novandrena) acutilabris Morawitz}

(Fig. 5: A-F)

Andrena acutilabris Morawitz, 1876, in Fedtschenko, Izv. Imp. Obschch. Ljubit. Estest. Antrop. Etnog.: 175 [female \& male, Uzbekistan].

Andrena (Nobandrena) acutilabris: Gusenleitner \& Schwarz, 2001, Entomofauna, 22: 96, Gusenleitner \& Schwarz, 2002, Entomofauna, Suupl., 12: 57.

Andrena urmitana Morawitz, 1876, in Fedtschenko, Izv. Imp. Obschch. Ljubit. Estest. Antrop. Etnog.: 175 [male, Tadzhikistan].

Redescription.

Female: BL $11.3 \mathrm{~mm}$, WL $8.0 \mathrm{~mm}(\mathrm{n}=1)$.

Color: Flagellum blackish brown beneath; mandible 


\section{O. TADAUCHI}

with apical half reddened; wing membranes subhyaline, moderately brownish, veins and pterostigma yellowish brown; tarsi and tibiae of all legs ferruginous; tibial spurs reddish yellow; posterior depressions of metasomal terga reddish brown.

Pubescence: Hairs on head and thorax sparse, pale yellow; those on clypeus 200-300 $\mu \mathrm{m}$; those on vertex without brown or black, $300-400 \mu \mathrm{m}$; those on genal area $300-400 \mu \mathrm{m}$; facial fovea yellowish brown. Hairs on mesoscutum 100-200 $\mu \mathrm{m}$, pale yellow, sparse; those on scutellum 200-300 $\mu \mathrm{m}$, yellow, dense; those on mesepisternum 500-600 $\mu \mathrm{m}$, yellowish; propodeal corbicula moderately developed without anterior fringes, internal area with long, sparse simple hairs; trochanteral floccus imperfect, sparse, yellowish; femoral floccus dense; tibial scopal hairs long, simple, golden. Hairs on metasomal terga 1-2 scanty; those on terga 3-4 very short, pale yellow; terga 1-4 with dense broad pale yellowish bands, broadly interrupted on tergum 1 , completed on terga 2-4; caudal fimbria yellowish brown; sterna 2-5 with long, yellowish subapical fimbriae.

Structure: Head: HL/HW = 0.97. HW: MsW: MtW = 3.1: 2.9: 3.2. Vertex very narrow, flat in frontal view, densely tessellate with dense minute PP. OOD: POD: $\mathrm{OCD}=1.1: 0.8: 0.2$. FL1 $>$ FL2+3, FL2 $=$ FL3 which are broader than long. Eyes with inner margins subparalleled. Facial fovea moderately broad above, occupying $1 / 2$ space between eye and lateral ocellus, attaining to a line at lower margins of antennal fossae, $\mathrm{FVL}=1.1$ $\mathrm{mm}, \mathrm{FVW}=0.3 \mathrm{~mm}$. Supraclypeal area densely tessellate with obscure minute PP. Face above antennal fossae with fine longitudinal rugulae and weak interrugal PP, shagreening surface. Facial quadrangle longer than broad (2.0:2.4). Clypeus nearly flat, surface densely tessellate with sparse small PРø $20 \mu \mathrm{m}$, IS = 1-3, without longitudinal median impunctate space, $\mathrm{CPL}=1.2 \mathrm{~mm}$.

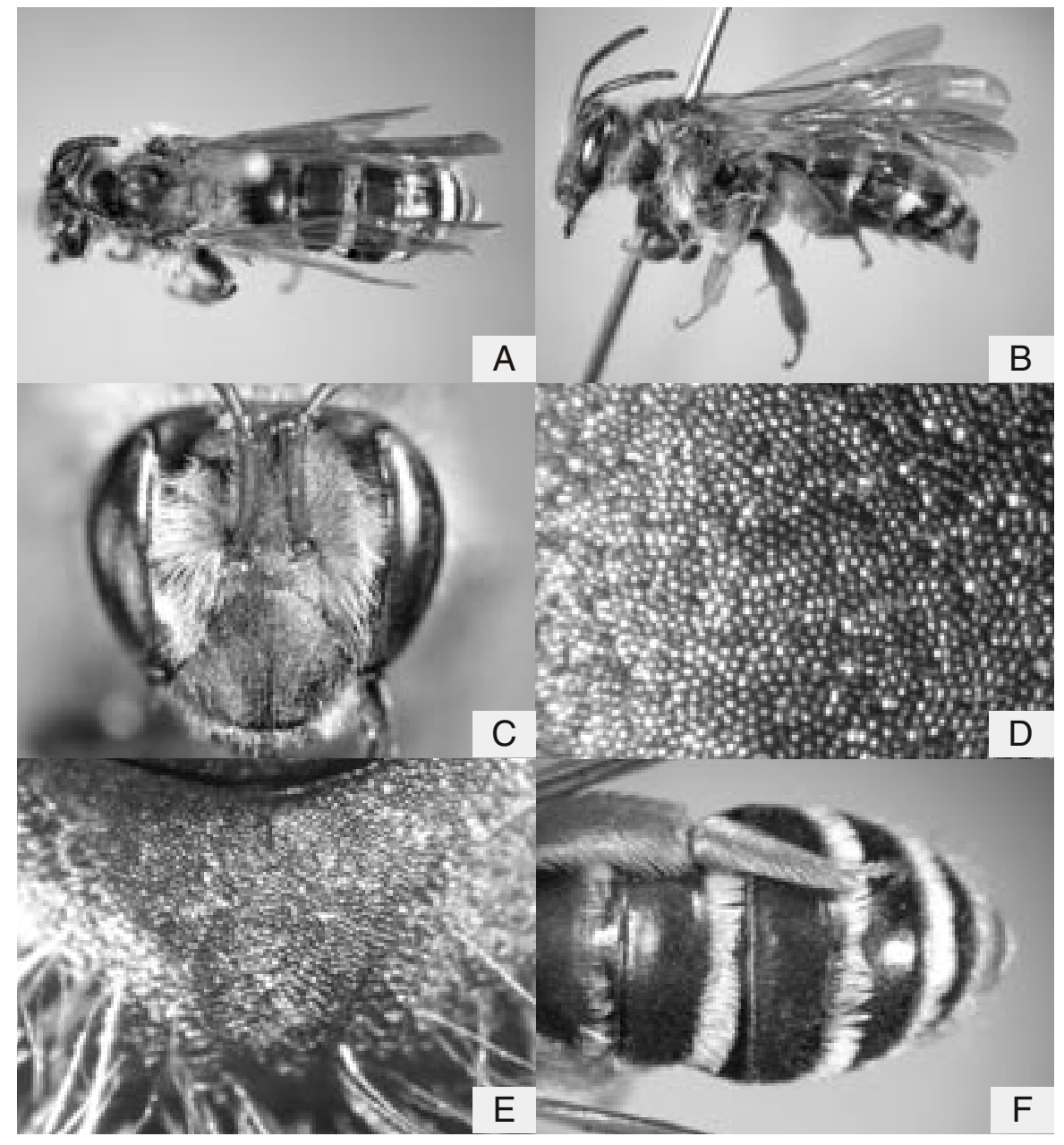

Fig. 5: A-F. Andrena (Novandrena) acutilabris Morawitz, female. A: general habitus in dorsal view; B: the same in lateral view; C: head in frontal view; D: mesoscutum; E: propodeum; F: metasomal terga. 
Process of labrum trapezoidal, entire medially. Lower paraocular area weakly tessellate and shiny with minute PP, IS $=1$. Malar space linear. Genal area broader than eye, GW: $\mathrm{EW}=0.7$ : 0.5 , surface broadly finely tesselate with minute PP. Mesosoma: Pronotum with long lateral suture and without humeral angle, surface weakly tessellate with minute PP. Mesoscutum densely tessellate with sparse, shallow, small PPø $20 \mu \mathrm{m}$, IS = 1-2. Scutellum densely tessellate with scattered obscure PP. Propodeal enclosure not rugulose, finely tessellate all over; dorsal face of propodeum finely tessellate with sparse obscure PP. Mesepisternum finely tessellate with sparse obscure PP. Vein 1st $m$ - $c u$ meeting second submarginal cell at middle of cell. Metasoma: Metasomal terga densely tessellate with obscure minute РРø20 $\mu$ $\mathrm{m}, \mathrm{IS}=1-2$; posterior depressions of terga not well indicated; pygidial plate $\mathrm{V}$-shaped, large, internal area with weak raised triangular area. Sterna 2-5 finely tessellate with obscure minute PP.

Specimens examined. [KAZAKHSTAN] 1 female, Baijansai 1030m, Mts. Karatau, S. Kazakhstan Prov., 9. vi. 2003 (O. Tadauchi).

Remarks. Similar species is not found in eastern Asia. The female is unique in having the vertex very narrow, the clypeus nearly flat and densely tessellate with sparse punctures, the pronotum with long lateral suture, and the propodeal enclosure not rugulose, finely tessellate all over.

Distribution. Uzbekistan, Tadzhikistan, Turkmenistan, Kazakhstan (new record).

Floral record. Not available.

\section{Andrena (Zonandrena) sibirica Morawitz} (Fig. 6: A-F)

Andrena sibirica Morawitz, 1888, Hor. Soc. Ent. Ross., 22: 239 [female, Middle Siberia]; Cockerell, 1928, Ann. Mag. Nat. Hist., (10) 1: 360.

Andrena (Melandrena) sibirica: Osytshnjuk, 1995, Key Insects Russian Far East in Six Volumes. Vol. 4: 504 [Russian Far East, in key].

Andrena (Zonandrena) sibirica: Gusenleitner \& Schwarz, 2001, Entomofauna, 22: 169; Gusenleitner \& Schwarz, 2002, Entomofauna, Suupl., 12: 694.

\section{Redescription.}

Female: BL $12.5 \mathrm{~mm}$, WL $9.2 \mathrm{~mm}(\mathrm{n}=1)$.

Color: Flagellum reddish brown beneath; mandible with apical half reddened; wing membranes subhyaline, moderately brown, veins and pterostigma blackish brown; tibial spurs yellowish brown; posterior depres- sions of metasomal terga dark reddish brown.

Pubescence: Hairs on head and thorax dense, pale yellowish to yellowish; those on clypeus $300-500 \mu$ $\mathrm{m}$; those on vertex $400-600 \mu \mathrm{m}$, with brownish; those on genal area $400-500 \mu \mathrm{m}$; facial fovea brown above, whitish below. Hairs on mesoscutum 300-400 $\mu$ m, yel-

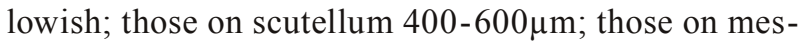
episternum $600-800 \mu \mathrm{m}$, pale yellowish; propodeal corbicula moderately developed, internal area with short, sparse simple hairs, without anterior fringes; trochanteral floccus imperfect, sparse, pale yellowish; femoral floccus dense; tibial scopal hairs long, simple, yellow. Hairs on metasomal terga 1-2 scanty; those on terga 3-4 rather short, dark brown; terga 2-4 with complete white hair bands, caudal fimbria dark brown; sterna 2-5 with long, sparse, pale yellowish subapical fimbriae.

Structure: Head: HL/HW = 0.83. HW: MsW: MtW $=3.5: 3.3: 3.8$. Vertex flat in frontal view, narrow, shagreened with close PP. OOD: POD: $\mathrm{OCD}=1.3$ : 1.1: 0.5. FL1 > FL2+3, FL2 $=$ FL3 which are broader than long. Eyes with inner margins paralleled. Facial fovea broad and long, occupying full space between eye and lateral ocellus above, extending to below a line at lower margins of antennal fossae, FVL $=2.0 \mathrm{~mm}, \mathrm{FVW}=$ $0.4 \mathrm{~mm}$. Supraclypeal area roughened with roughened PP. Face above antennal fossae with fine longitudinal rugulae and weak interrugal $\mathrm{PP}$, shagreening surface. Facial quadrangle quadrate (2.5: 2.5). Clypeus well convex, surface smooth and shiny with distinct, dense PP $ø 20 \mu \mathrm{m}, \mathrm{IS}=1$, without longitudinal median impunctate space, $\mathrm{CPL}=1.1 \mathrm{~mm}$. Process of labrum trapezoidal. Lower paraocular area smooth and shiny with minute $\mathrm{PP}, \mathrm{IS}=0.5$. Malar space linear. Genal area broader than eye, GW: EW = 1.0: 0.6, surface densely tesselate with obscure minute PP all over. Mesosoma: Pronotum with lateral suture and without humeral angle, surface weakly tessellate with minute PP. Mesoscutum weakly tessellate and weakly shiny with dense, small PPø20-30 $\mu \mathrm{m}$, IS $<0.5$. Scutellum weakly tessellate with small PP. Propodeal enclosure rugulose at basal $1 / 2$, finely tessellate apically; dorsal face of propodeum shagreened with roughened PP. Mesepisternum densely tessellate, a little roughened with obscure PP. Vein 1st $m$-cu meeting second submarginal cell at middle of cell. Metasoma: Metasomal terga weakly tessellate with dense, small PP $\varnothing 20 \mu \mathrm{m}$, IS $<0.5$; posterior depressions of terga not well indicated; pygidial plate V-shaped, internal area with weak raised triangular area. Sterna 2-5 weakly tessellate and shiny with minute PP.

Specimens examined. [KAZAKHSTAN] 1 female, Achisai 670-700m, Mts. Karatau, S. Kazakhstan Prov., 


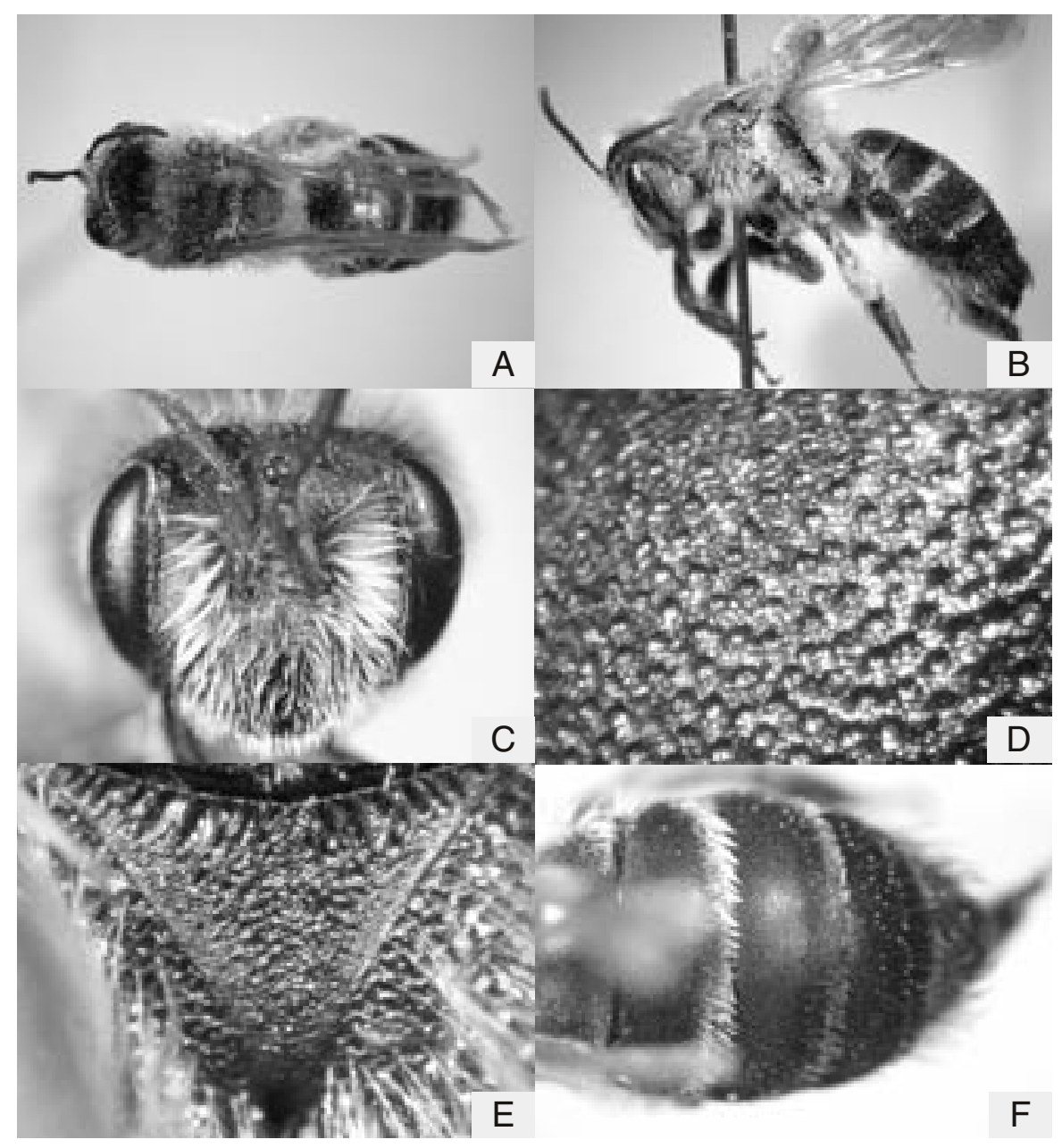

Fig. 6: A-F. Andrena (Zonandrena) sibirica Morawitz, female. A: general habitus in dorsal view; B: the same in lateral view; C: head in frontal view; D: mesoscutum; E: propodeum; F: metasomal terga.

4. vi. 2003 (O. Tadauchi).

Remarks. This species is similar to Andrena flavipes Panzer which is distributed from Europe to eastern Asia, but the female can be separated from that of flavipes by the thorax with yellowish hairs, the facial fovea above occupying full space between eye and lateral ocellus and the caudal fimbria dark brown.

Distribution. Russia (Middle Siberia, Russian Far East), Kazakhstan (new record).

Floral record. Not available.

\section{Andrena (Lepidandrena) punctiventris Morawitz}

(Figs. 7: A-F; 8: A-F)

Andrena punctiventris Morawitz, 1876, in Fedtschenko, Izv. Imp. Obschch. Ljubit. Estest. Antrop. Etnog.: 187 [female, Uzbekistan].

Andrena (Poliandrena) punctiventris basagiensis Osytshnjuk, 1994, Vest. Zool., 1: 30 [Tadzhikistan].
Andrena (Lepidandrena) punctiventris: Gusenleitner \& Schwarz, 2001a, Entomofauna, 21: 156, Gusenleitner \& Schwarz, 2002, Entomofauna, Suupl., 12: 618.

Redescription.

Female: BL 10.5-11.3 mm, WL 8.8-9.2 mm ( $\mathrm{n}=7)$.

Color: Flagellum ferruginous beneath; mandible with apical third reddened; wing membranes subhyaline, moderately brown, veins and pterostigma blackish brown; mid tarsi and hind tibiae and tarsi ferruginous; tibial spurs reddish yellow; metasomal terga 1-4 ferruginous in part; metasomal terga ferruginous in part; posterior depressions of metasomal terga reddish yellow.

Pubescence: Hairs on head and thorax moderately dense, black; those on clypeus 200-300 $\mu \mathrm{m}$; those on vertex $400 \mu \mathrm{m}$; those on genal area $400-600 \mu \mathrm{m}$; facial fovea black. Hairs on mesoscutum $100 \mu \mathrm{m}$, short, black; those on scutellum $40 \mu \mathrm{m}$; those on mesepisternum 
300-500 $\mu \mathrm{m}$; propodeal corbicula poorly developed, internal area with short, sparse simple hairs, without anterior fringes; trochanteral floccus perfect, long, dense, well curled, dull whitish; femoral floccus dense; tibial scopal hairs long, simple, golden. Hairs on metasomal terga 1-2 scanty; those on terga 3-4 very short, black; terga 2-4 with yellow hair bands, broadly interrupted on tergum 2, completed on terga 3-4; caudal fimbria brown; sterna 2-5 with long, sparse, black subapical fimbriae.

Structure: Head: HL/HW $=0.85$. HW: MsW: MtW $=$ 3.3: 3.2: 3.5. Vertex flat in frontal view, shagreened with roughened PP. OOD: POD: $O C D=1.0: 0.9: 0.6$. FL1 $=\mathrm{FL} 2+3, \mathrm{FL} 2=\mathrm{FL} 3$ which are as broad as long. Eyes with inner margins paralleled. Facial fovea occupying $2 / 3$ space between eye and lateral ocellus, extending to a line at lower margins of antennal fossae, $\mathrm{FVL}=1.5$ $\mathrm{mm}, \mathrm{FVW}=0.5 \mathrm{~mm}$. Supraclypeal area shagreened with roughened PP. Face above antennal fossae with fine longitudinal rugulae and weak interrugal PP, shagreening surface. Facial quadrangle quadrate (2.2: 2.2). Clypeus moderately convex, surface weakly tessellate and shiny below, densely tessellate above with small, shallow PРø30 $\mu \mathrm{m}$, IS $=0.5$, without longitudinal median impunctate space, $\mathrm{CPL}=1.2 \mathrm{~mm}$. Process of labrum shiny, trapezoidal with apex reflected, emarginated medially. Lower paraocular area smooth and shiny with minute, shallow PP, IS $<0.5$. Malar space linear. Genal area broader than eye, $\mathrm{GW}: \mathrm{EW}=0.9$ : 0.6, surface weakly tessellate and shiny with minute PP posteriorly, narrowly smooth and shiny near eye. Mesosoma: Pronotum without lateral suture and humeral angle, surface weakly tessellate and shiny with minute PP. Mesoscutum smooth and shiny with distinct, small PPø30 $\mu \mathrm{m}, \mathrm{IS}=0.5$. Scutellum smooth and shiny with distinct, small PP. Propodeal enclosure weakly rugulose at basal

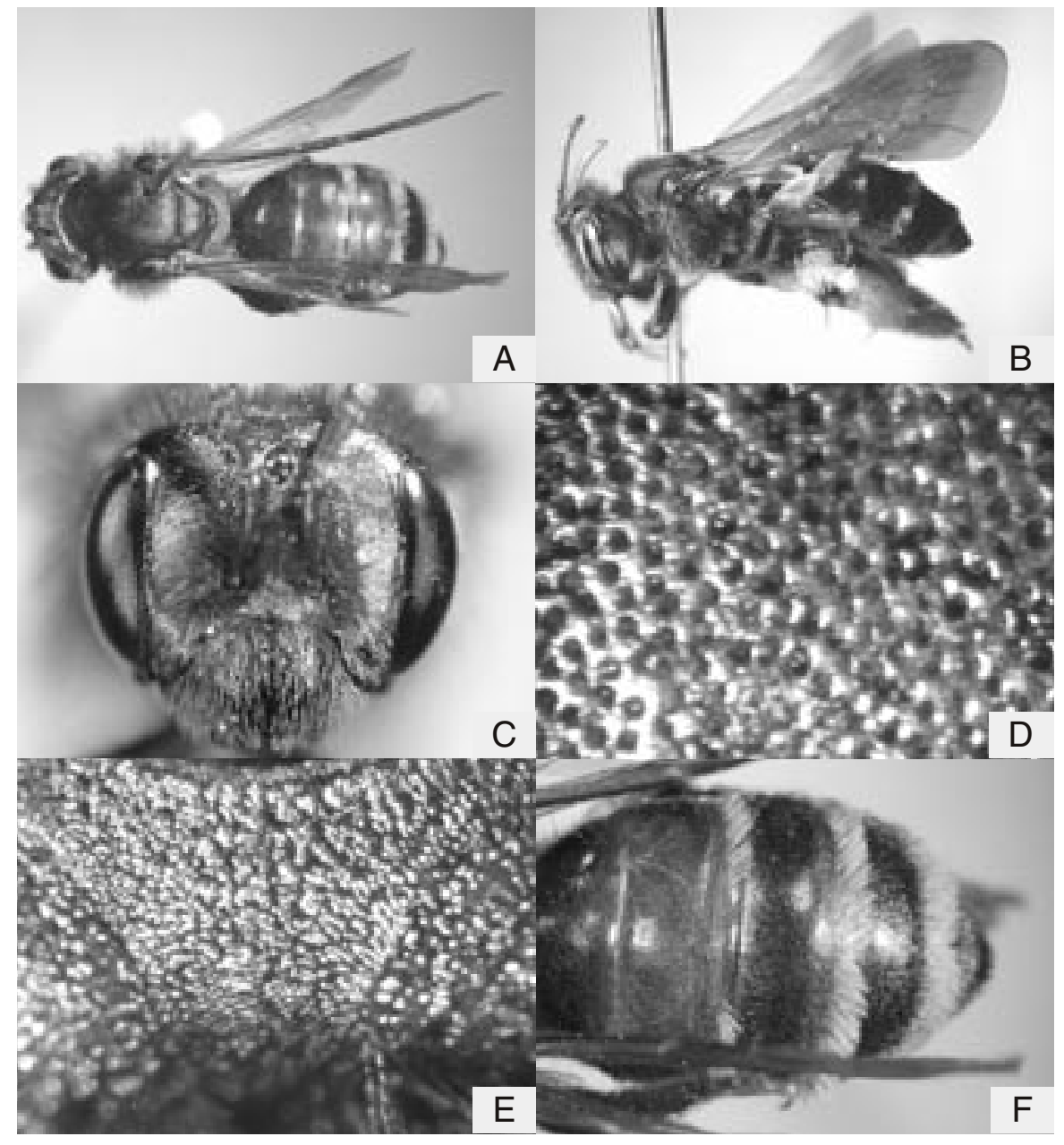

Fig. 7: A-F. Andrena (Lepidandrena) punctiventris Morawitz, female. A: general habitus in dorsal view; B: the same in lateral view; C: head in frontal view; D: mesoscutum; E: propodeum; F: metasomal terga. 


\section{O. TADAUCHI}

$1 / 4$, shagreened apically; dorsal face of propodeum shagreened with roughened PP. Mesepisternum densely tessellate, a little roughened with obscure PP. Vein 1st $m$-cu meeting second submarginal cell at middle of cell. Metasoma: Metasomal terga smooth and shiny with dense, distinct PPø20 $\mu \mathrm{m}$, IS $<0.5$; posterior depressions of terga weakly indicated; pygidial plate V-shaped, internal area with raised triangular area. Sterna 2-5 densely tessellate with minute PP.

Male: BL 10.7-10.9 mm, WL 8.2-8.4 mm (n=2).

Color. Flagellum ferruginous; clypeus yellow except two triangular spots below tentorial pits; mandible with apical third reddened; wing membranes subhyaline, weakly brown, veins and pterostigma reddish brown; tibial spurs reddish yellow; metasomal terga 1-4 broadly ferruginous; posterior depressions of metasomal terga reddish yellow.

Pubescence. Hairs on head and thorax not dense, pale yellow; those on vertex 400-600 $\mu \mathrm{m}$, without brownish; those on genal area $400-500 \mu \mathrm{m}$; those on mesoscutum $400-500 \mu \mathrm{m}$, pale yellow; those on posterior margin of scutellum long and dense; propodeum and mesepisternum with sparse, whitish hairs. Hairs on metasomal terga short, pale yellowish; terga 2-4 with pale hair bands, not dense; sterna 2-5 with dense, curled, pale yellowish subapical fimbriae.

Structure. Head: HL/ HW =0.84. HW: MsW: MtW = 3.2: 3.0: 3.2. Vertex round, shagreened with roughened PP. OOD: POD: $\mathrm{OCD}=1.2: 0.9: 0.5$. FL1 < FL2+3, FL2 $<$ FL3. Eyes with inner margins subparalleled. Supraclypeal area and face above antennal fossae sculptured as in female. Facial quadrangle quadrate (2.1:2.1). Clypeus strongly convex, smooth and shiny, surface scattered relatively large PPø30-40 $\mu \mathrm{m}, \mathrm{IS}=1-2, \mathrm{CPL}$ $=1.0 \mathrm{~mm}$. Process of labrum large, strongly emarginate medially. Mandibles long. Lower paraocular area

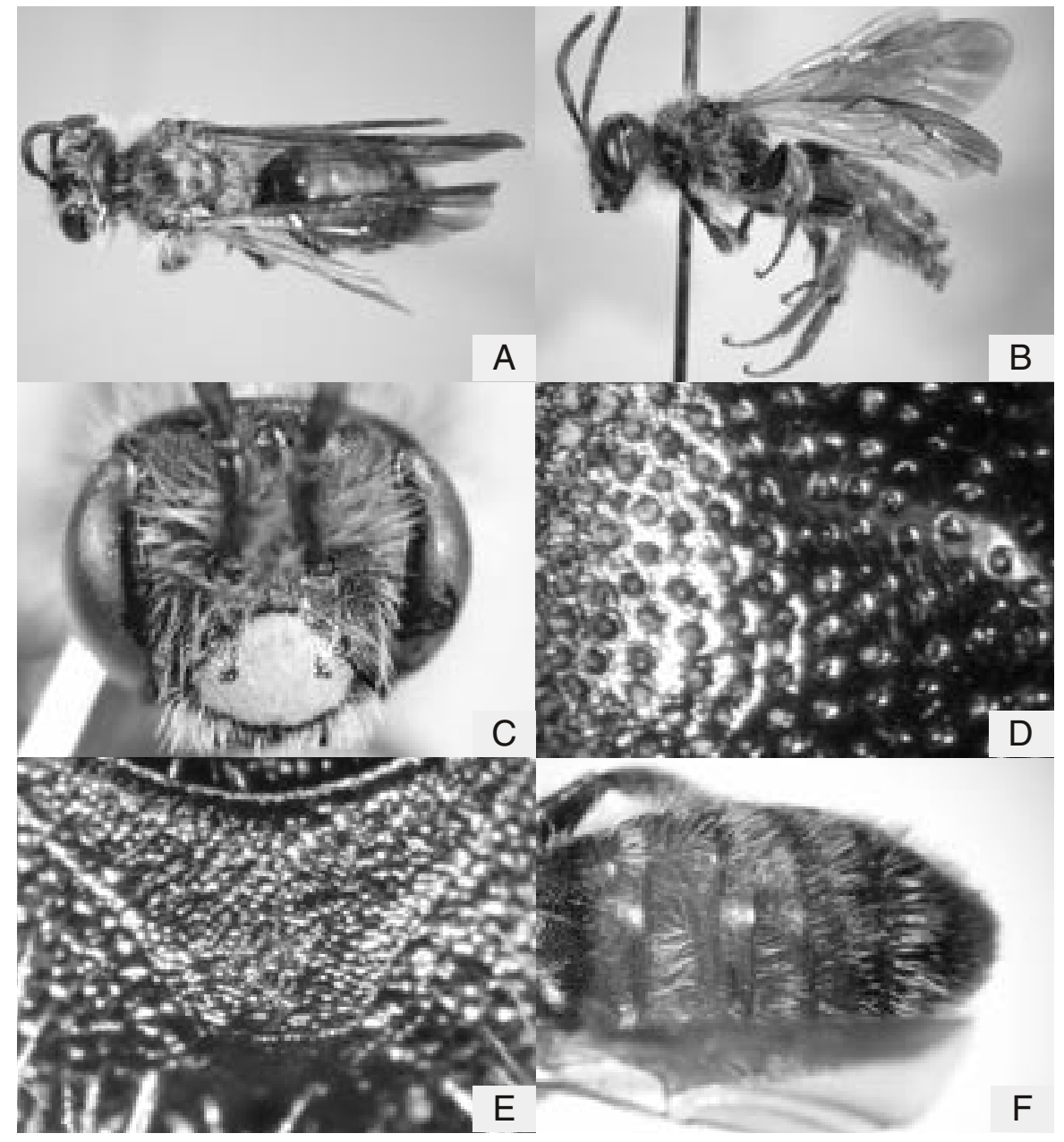

Fig. 8: A-F. Andrena (Lepidandrena) punctiventris Morawitz, male. A: general habitus in dorsal view; B: the same in lateral view; C: head in frontal view; D: mesoscutum; E: propodeum; F: metasomal terga. 
smooth and shiny with minute PP, IS $<0.5$. Malar space linear. Genal area as broad as eye, $\mathrm{GW}$ : $\mathrm{EW}=0.7$ : 0.7, surface broadly smooth and shiny with roughened PP. Mesosoma: Pronotum without lateral suture and humeral angle, surface smooth and shiny with minute PP; pronotum with anterior margin emarginate medially. Mesoscutum smooth and shiny with distinct, small PP $\varnothing 30 \mu \mathrm{m}$, IS $=0.5-2$. Scutellum smooth and shiny with distinct, small PP. Propodeum shagreened all over. Mesepisternum weakly tessellate with roughened PP. Venation as in female. Metasoma: Metasomal terga smooth and shiny with dense, distinct PPø30 $\mu \mathrm{m}, \mathrm{IS}=1$; posterior depressions of terga well indicated. Sterna 2-5 smooth and shiny with scattered minute PP.

Specimens examined. [KAZAKHSTAN] 1 male, Achisai 670m, Mts. Karatau, S. Kazakhsatan Prov., 3. vi. 2003 (K. Mitai); 3 females, Seslavino 960m, Daubaba River, S. Kazakhstan Prov., 11. vi. 2003 (O. Tadauchi); 4 females, Daubaba 700m, S. Kazakhstan Prov., 13. vi. 2003 (O. Tadauchi); 1 male, Kashi-Kaindy 1700m, Jabagly, S. Kazakhstan Prov., 15. vi. 2003 (O. Tadauchi).

Remarks. Similar species is not found from eastern Asia up to now. It is characteristic in having the flagellum ferruginous, the process of labrum shiny, trapezoidal with apex reflected, emarginated in the middle, the metasomal terga ferruginous in part, and the male clypeus yellow.

Distribution. Uzbekistan, Tadzhikistan, Kazakhstan (new record).

Floral record. Ferula tenuisecta.

\section{Andrena (Micrandrena) aiderensis Osytshnjuk} (Figs. 9: A-F; 10: A-F)

Andrena (Micrandrena) aiderensis Osytshnjuk, 1993, Ent. Obozr., 72: 408 [female \& male, Azerbaidjan]; Osytshnjuk, 1994, Ent. Review, 73: 83; Gusenleitner \& Schwarz, 2000, Entomofauna, 21: 384, Gusenleitner \& Schwarz, 2002, Entomofauna, Suupl., 12: 67.

\section{Redescription.}

Female: BL 7.0-7.3 mm, WL 5.0-5.4 mm ( $\mathrm{m}=7)$.

Color: Flagellum brownish beneath; mandible with apical half reddened; wing membranes subhyaline, veins and pterostigma yellowish brown; tibial spurs yellow; posterior depressions of metasomal terga reddish brown.

Pubescence: Hairs on head and thorax sparse, white to dull whitish; those on clypeus $160 \mu \mathrm{m}$; those on vertex $200 \mu \mathrm{m}$, without brown or blackish; those on genal area $160-200 \mu \mathrm{m}$; facial fovea white. Hairs on mesoscutum 100-200 $\mu \mathrm{m}$, white; those on scutellum 150-200 $\mu \mathrm{m}$; those on mesepisternum $300-400 \mu \mathrm{m}$, white; propodeal corbicula moderately developed, internal area with short, sparse simple hairs; trochanteral floccus imperfect, sparse, whitish; femoral floccus dense; tibial scopal hairs long, simple, white. Hairs on metasomal tergum 1 scanty; terga 2-4 with short, white lateral hairs, not composing hair bands; caudal fimbria yellow; sterna 2-5 with long, relatively dense, dull white subapical fimbriae.

Structure: Head: HL/HW $=0.82$. HW: MsW: MtW $=2.1: 2.2: 2.4$. Vertex round in frontal view, shagreened by dense tessellation and punctation OOD: POD: OCD $=0.8: 0.7: 0.2$. FL1 < FL2+3, FL2 = FL3 which are broader than long. Eyes with inner margins subparalleled. Facial fovea narrow, extending to below a line at lower margins of antennal fossae, FVL $=1.0 \mathrm{~mm}$, FVW $=0.2 \mathrm{~mm}$. Supraclypeal area roughened by coarse lugulae. Face above antennal fossae with fine longitudinal rugulae and weak interrugal $\mathrm{PP}$, shagreening surface. Facial quadrangle quadrate (1.5: 1.5). Clypeus well convex medially, surface smooth and shiny with PPø $30-40 \mu \mathrm{m}$, IS $>0.5, \mathrm{CPL}=0.8 \mathrm{~mm}$, without longitudinal median impunctate space. Process of labrum short, trapezoidal, entire apically. Lower paraocular area smooth and shiny with roughened PP, IS $>0.5$. Malar space linear. Genal area broader than eye, GW: EW = 0.4: 0.4 , surface broadly finely tessellate with obscure PP, narrowly shiny with PP near eye. Mesosoma: Pronotum with lateral suture and without humeral angle, surface very weakly tessellate and shiny with sparse PP. Mesoscutum finely tessellate anteriorly, smooth and shiny centally with distinct $\mathrm{PP} \varnothing 20 \mu \mathrm{m}$, IS $=0.5$ - 1 . Scutellum smooth and shiny with distinct PP. Propodeal enclosure rugulose all over; dorsal face of propodeum rugulose. Mesepisternum densely tessellate, shagreened with roughened PP. Vein 1st $m$-cu meeting second submarginal cell at middle of cell. Metasoma: Metasomal terga smooth and shiny with distinct PP. Tergum 1 with dense PP except narrow apical area, PРø20 $\mu \mathrm{m}$, IS > 0.5; terga 2-4 with PРø20 $\mu \mathrm{m}$, IS $=0.5$; posterior depressions of terga well indicated, broad; pygidial plate V-shaped, internal area with weak raised triangular area. Sterna 2-5 weakly tessellate, impunctate at basal halves, finely punctate at apical halves.

Male: BL 6.4-6.6 mm, WL 4.7-4.8 mm $(\mathrm{n}=2)$.

Color. Flagellum blackish brown beneath; mandible with apical third reddened; wing membranes subhyaline, weakly brown, veins and pterostigma yellowish brown; tibial spurs pale yellow; posterior depressions of 


\section{O. TADAUCHI}

metasomal terga reddish brown.

Pubescence. Hairs on head and thorax scanty, white; those on vertex 200-250 $\mu \mathrm{m}$, without brownish; those on genal area $300-400 \mu \mathrm{m}$; those on mesoscutum $200 \mu$ $\mathrm{m}$, sparse; those on posterior margin of scutellum long; propodeum and mesepisternum with relatively dense, long, whitish hairs. Hairs on metasomal terga short, white; terga 1-4 with white hair bands, broadly interrupted; sterna 2-5 with long, sparse, whitish subapical fimbriae.

Structure. Head: HL/ HW =0.95. HW: MsW: MtW $=1.9: 1.8: 1.9$. Vertex round in frontal view, shagreened with roughened PP. OOD: POD: $\mathrm{OCD}=0.9$ : 0.5: 0.3. FL1 < FL2+3, FL2 = FL3. Eyes with inner margins subparalleled. Supraclypeal area smooth and shiny with distinct PP. Face above antennal fossae sculptured as in female. Facial quadrangle longer than broad (1.4: 1.5). Clypeus strongly convex, smooth and shiny, sur- face scattered distinct small PPø20 $\mu \mathrm{m}, \mathrm{IS}=1-2, \mathrm{CPL}=$ $0.8 \mathrm{~mm}$. Process of labrum rectangular, shiny, weakly emarginate medially. Mandibles not decussate. Lower paraocular area smooth and shiny with minute PP, IS =1-2. Malar space linear. Genal area narrower than eye, GW: EW =0.4: 0.5, surface smooth and shiny with small PP. Mesosoma: Pronotum with lateral suture and without humeral angle, surface smooth and shiny with minute PP. Mesoscutum smooth and polished with small PPø20 $\mu \mathrm{m}$, IS = 1-3. Scutellum smooth and polished with small PP. Propodeum large, lugulose all over with dorsal face of propodeum strongly roughened. Mesepisternum shagreened with roughened PP. Venation as in female. Metasoma: Metasomal terga smooth and shiny with dense, distinct, small PPø20 $\mu \mathrm{m}$, IS < 0.5 ; posterior depressions of terga well indicated. Sterna 2-5 smooth and shiny with a little roughened PP.

Specimens examined. [KAZAKHSTAN] Near Stern-

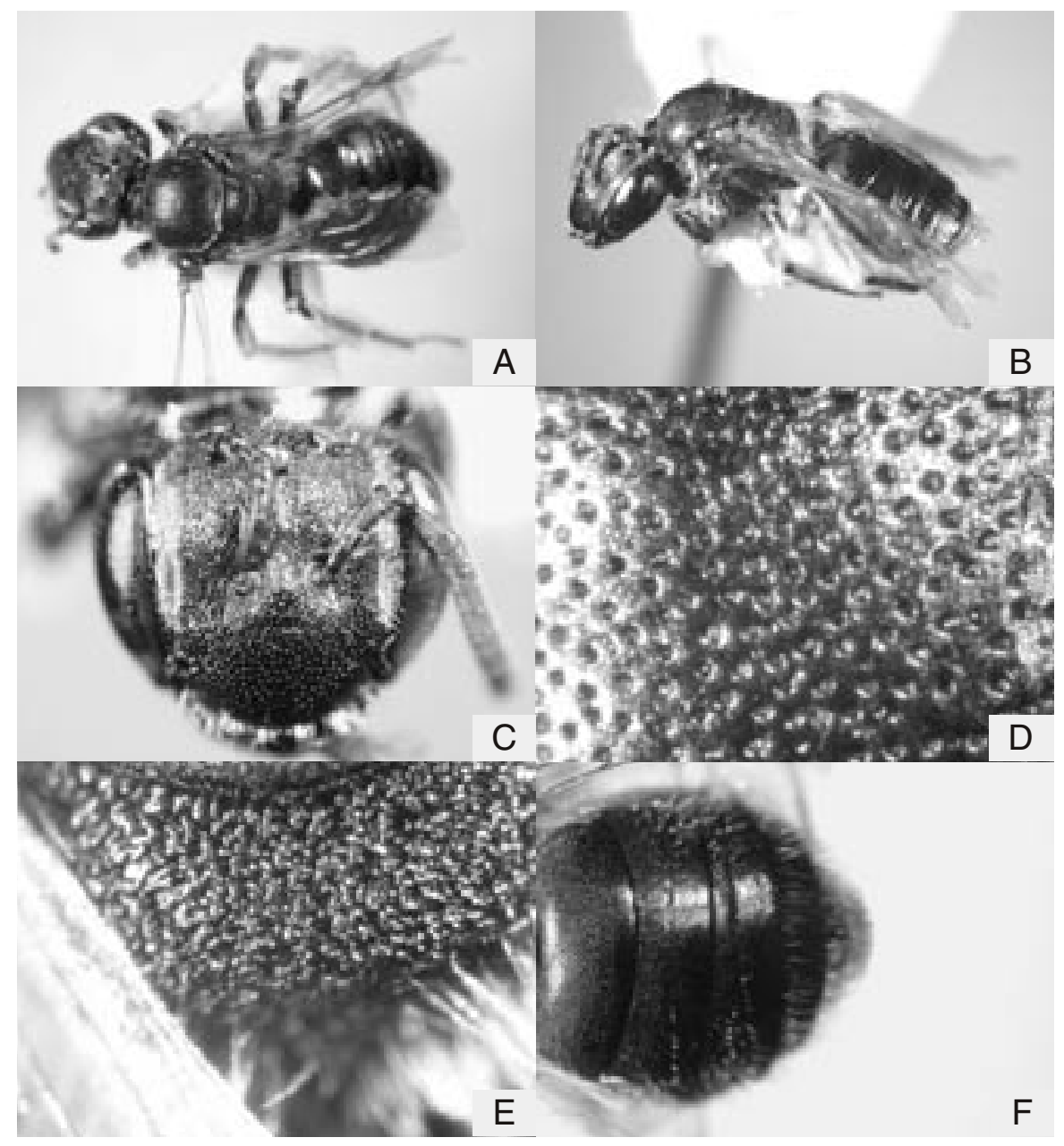

Fig. 9: A-F. Andrena (Micrandrena) aiderensis Osytshnjuk, female. A: general habitus in dorsal view; B: the same in lateral view; C: head in frontal view; D: mesoscutum; E: propodeum; F: metasomal terga. 


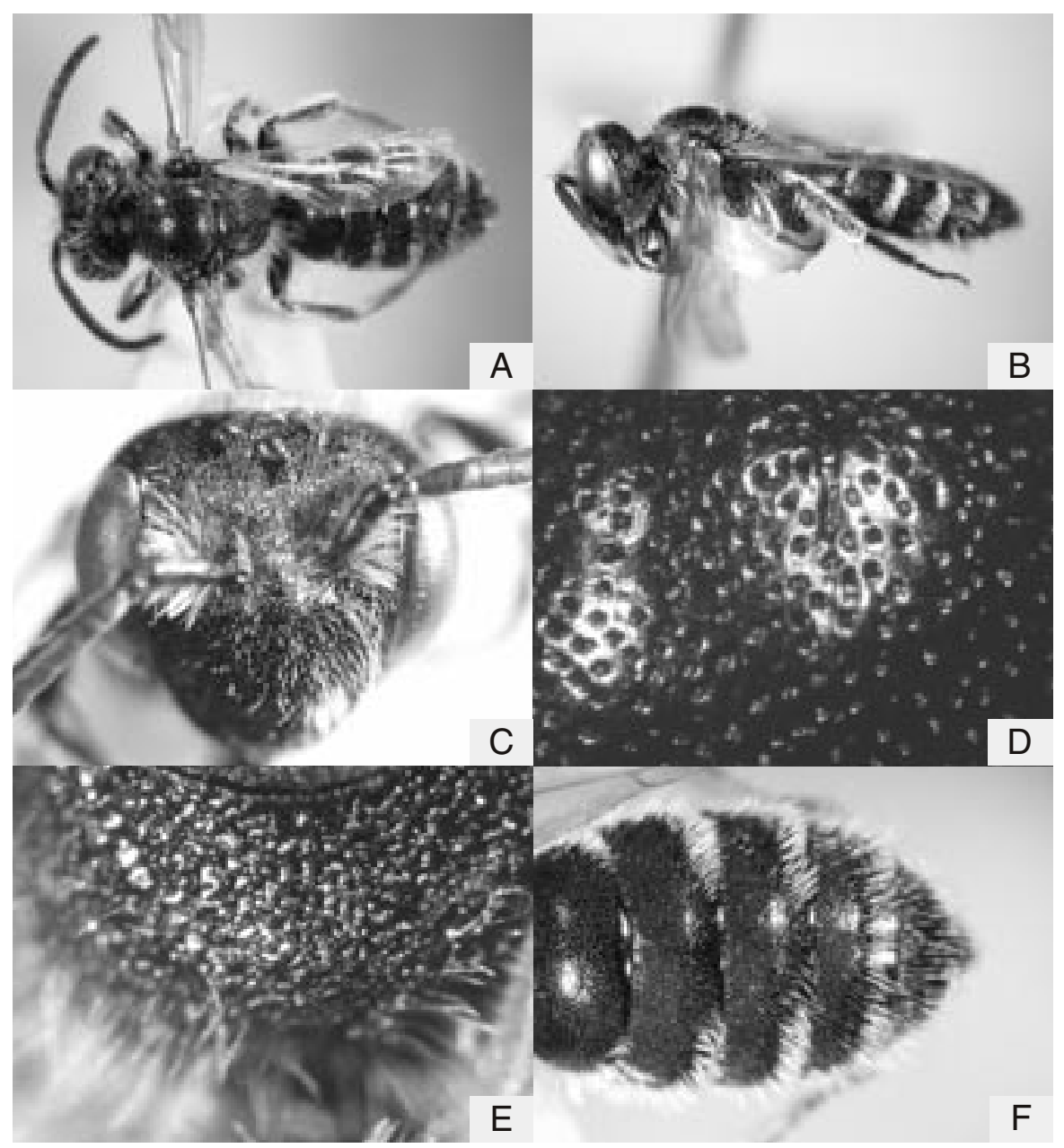

Fig. 10: A-F. Andrena (Micrandrena) aiderensis Osytshnjuk, male. A: general habitus in dorsal view; B: the same in lateral view; C: head in frontal view; D: mesoscutum; E: propodeum; F: metasomal terga.

jak, Kokchetav District, N. Kazakhstan Prov. (V. Kazanas, A. Jashenko \& V. Kastcheev): 3 females, 17. vi. 2002; 1 female, 23. vi. 2002; 2 females, 28. vi. 2002; 2 males, 23. vii. 2002; 1 female, 29.vii. 2002.

Remarks. This species is somewhat similar to Andrena komachi Hirashima from eastern Asia, but it can be separated from that of komachi by the clypeus strongly convex and smooth and shiny with distinct punctures, the propodeal enclosure less rugulose, the metasomal terga smooth and shiny with dense distinct punctures, the male clypeus without dense white hairs and the male metasomal sterna without dense white subapical fimbriae.

Distribution. Azerbaidjan, Kazakhstan (new record).

Floral record. Not available.

\section{Andrena (Poecilandrena) semiaenea Morawitz (Fig. 11: A-F)}

Andrena semiaenea Morawitz, 1876, in Fedtschenko,
Izv. Imp. Obschch. Ljubit. Estest. Antrop. Etnog.: 213 [female, Uzbekistan].

Andrena (Lepidandrena) semiaenea: Xu \& Tadauchi, 1997, J. Fac. Agr., Kyushu Univ., 41: 171.

Andrena (Poecilandrena) semiaenea: Gusenleitner \& Schwarz, 2002, Entomofauna, Suupl., 12: 680-682.

\section{Redescription.}

Female: BL $7.2 \mathrm{~mm}$, WL $5.2 \mathrm{~mm}(\mathrm{n}=1)$.

Color: Flagellum ferruginous beneath; mandible with apical third reddened; wing membranes subhyaline, pale brown, veins and pterostigma yellowish brown; tibial spurs yellow; metasomal terga 1-4 ferruginous in part; posterior depressions of metasomal terga reddish yellow.

Pubescence: Hairs on head and thorax sparse, dull whitish; those on clypeus $80-100 \mu \mathrm{m}$; those on vertex $100-120 \mu \mathrm{m}$; those on genal area $100-150 \mu \mathrm{m}$; facial fovea white. Hairs on mesoscutum $40-50 \mu \mathrm{m}$, dull whit- 


\section{O. TADAUCHI}

ish, very short velutinous; those on scutellum $40-50 \mu$ $\mathrm{m}$; those on mesepisternum $200-300 \mu \mathrm{m}$, whitish; propodeal corbicula moderately developed, internal area with short, sparse simple hairs, without anterior fringes; trochanteral floccus imperfect, sparse, whitish; femoral floccus dense; tibial scopal hairs long, simple, whitish. Hairs on metasomal terga 1-2 scanty; those on terga 3-4 rather short, whitish; terga 2-4 without white hair bands, only sparse hairs apically; caudal fimbria bright yellow; sterna 2-5 with long, sparse, whitish subapical fimbriae.

Structure: Head: HL/HW = 0.91. HW: MsW: MtW = 2.3: 2.1: 2.3. Vertex flat in frontal view, narrow, weakly tessellate and shiny with shallow PP. OOD: POD: OCD $=0.8: 0.7: 0.2$. FL1 $=$ FL2 +3 , FL2 $=$ FL3 which are as broad as long. Eyes with inner margins paralleled. Facial fovea occupying $1 / 2$ space between eye and lateral ocellus, attaining to a line at lower margins of antennal fossae, FVL $=0.9 \mathrm{~mm}$, FVW $=0.2 \mathrm{~mm}$. Supraclypeal area shagreened with close PP. Face above antennal fossae with fine longitudinal rugulae and weak interrugal PP, shagreening surface. Facial quadrangle longer than broad (1.5: 1.7). Clypeus nearly flat, surface smooth and shiny with sparse small PPø20 $\mu \mathrm{m}$, IS =1-2, with longitudinal median impunctate space, $\mathrm{CPL}=0.8 \mathrm{~mm}$. Process of labrum short, semi-circular. Lower paraocular area smooth and shiny with minute PP, IS=1-2. Malar space linear. Genal area broader than eye, GW: $\mathrm{EW}=0.5: 0.4$, surface very weakly tesselate and shiny with minute PP. Mesosoma: Pronotum with obscure lateral suture and without humeral angle, surface very weakly tessellate and shiny with minute PP. Mesoscutum smooth and shiny with distinct, small PPø20 $\mu \mathrm{m}$, IS $=0.5-1$. Scutellum smooth and shiny with distinct, small PP. Propodeal enclosure weakly rugulose at basal $1 / 3$, finely tessellate apically; dorsal face of propodeum

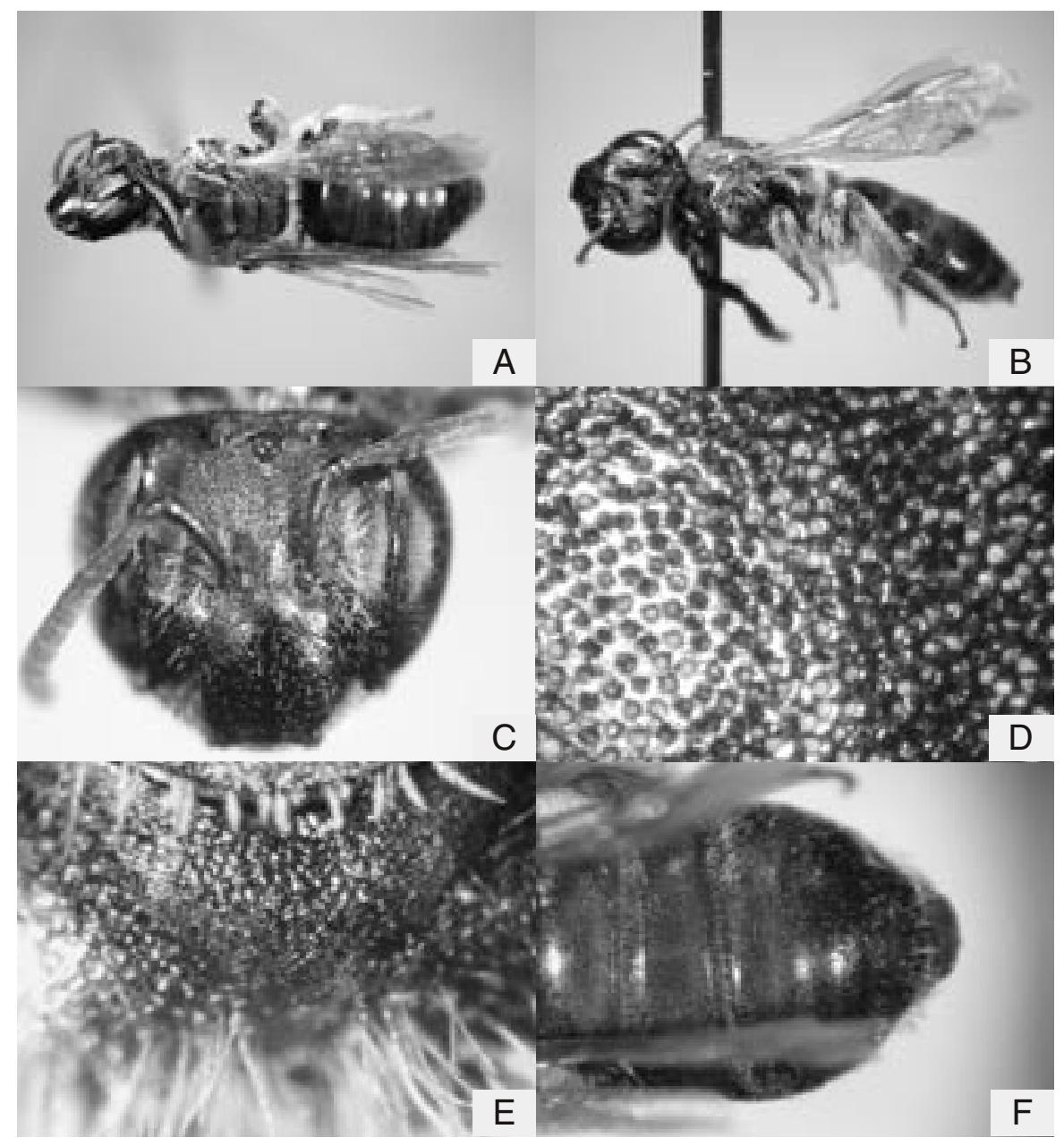

Fig. 11: A-F. Andrena (Poecilandrena) semiaenea Morawitz, female. A: general habitus in dorsal view; B: the same in lateral view; C: head in frontal view; D: mesoscutum; E: propodeum; F: metasomal terga. 
shagreened with roughened PP. Mesepisternum densely tessellate, a little roughened with obscure PP. Vein 1st $m$-cu meeting second submarginal cell at middle of cell. Metasoma: Metasomal terga smooth and shiny with dense, distinct PPø20 $\mu \mathrm{m}, \mathrm{IS}=1-2$; posterior depressions of terga well indicated; pygidial plate V-shaped, internal area with weak raised triangular area. Sterna 2-5 weakly tessellate and shiny with minute PP.

Specimens examined. [KAZAKHSTAN] 1 female, Polevod, riverside Syrdarya River, S. Kazakhstan Prov., 9. v. 2004 (O. Tadauchi).

Remarks. This species is somewhat similar to Andrena subsquamiformis Tadauchi et Xu from eastern Asia, but the female can be separated from that of subsquamiformis by the process of labrum short semi-circular, the mesoscutum smooth and shiny with distinct punctures, with dull whitish very short velutinous hairs, the metasomal terga smooth and shiny with dense distinct punc- tures, and the terga 2-4 without hair bands.

Distribution. Uzbekistan, Kazakhstan (new record). Floral record. Not available.

\section{Andrena (Poecilandrena) mucorea Morawitz} (Fig. 12: A-F)

Andrena mucorea Morawitz, 1876, in Fedtschenko, Izv. Imp. Obschch. Ljubit. Estest. Antrop. Etnog.: 212 [female \& male, Uzbekistan].

Andrena (Poecilandrena) mucorea: Gusenleitner \& Schwarz, 2001, Entomofauna, 22: 143; Gusenleitner \& Schwarz, 2002, Entomofauna, Suupl., 12: 499-500.

\section{Redescription.}

Female: BL $8.9 \mathrm{~mm}$, WL $5.3 \mathrm{~mm}(\mathrm{n}=1)$.

Color: Head and thorax with metallic blue reflections; Flagellum ferruginous beneath; mandible red-

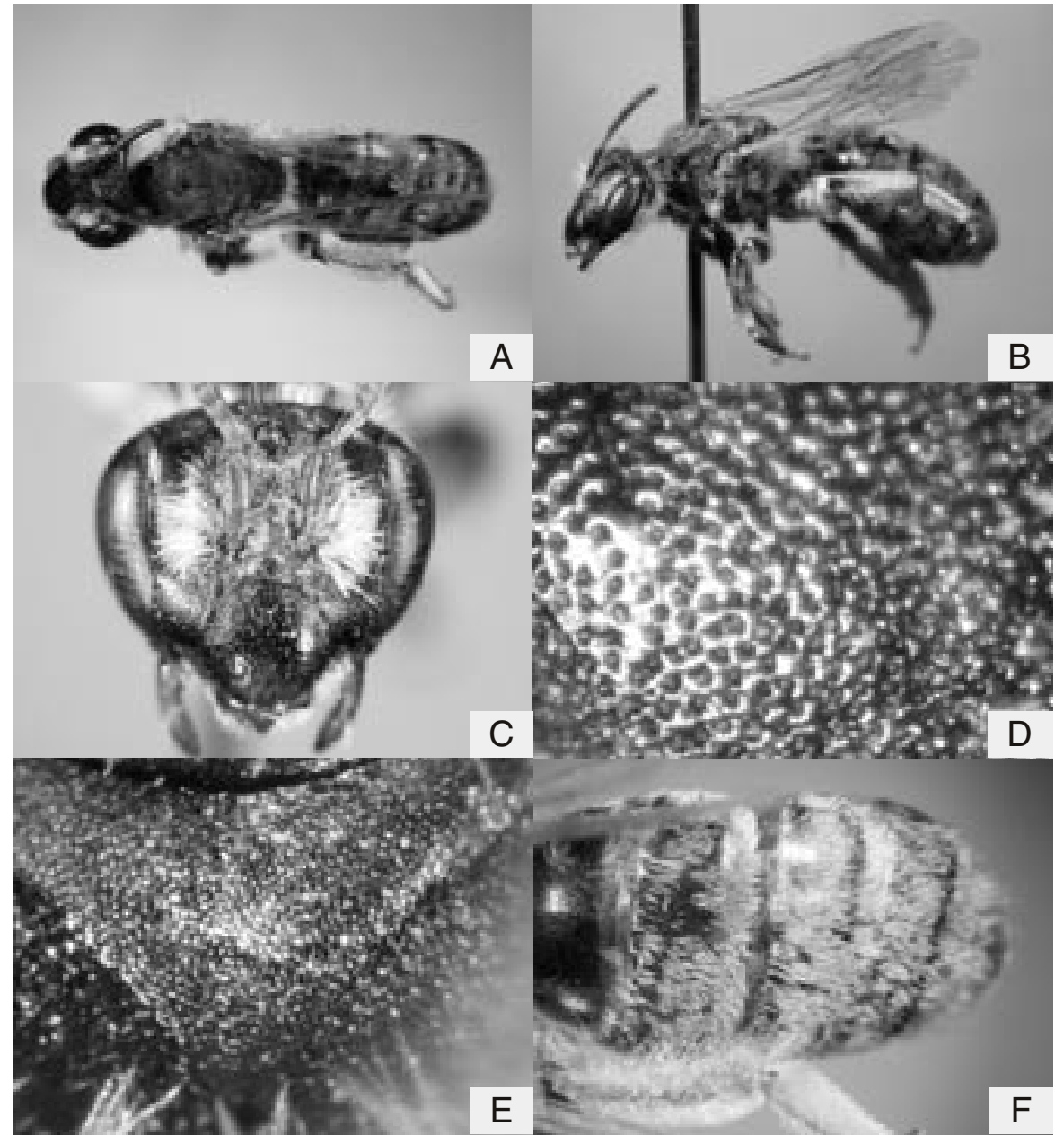

Fig. 12: A-F. Andrena (Poecilandrena) mucorea Morawitz, female. A: general habitus in dorsal view; B: the same in lateral view; C: head in frontal view; D: mesoscutum; E: propodeum; F: metasomal terga. 


\section{O. TADAUCHI}

dened; clypeus with lower part and process of labrum ferruginous; wing membranes subhyaline, pale brown, veins and pterostigma yellowish brown; tibiae in part and tarsi ferruginous; tibial spurs yellow; metasomal terga 1-4 ferruginous in part; posterior depressions of metasomal terga yellowish brown.

Pubescence: Hairs on head and thorax sparse except antennal area, whitish; those on clypeus 40-50 $\mu \mathrm{m}$; those on vertex 250-300 $\mu \mathrm{m}$, without brownish; those on genal area $200-300 \mu \mathrm{m}$; facial fovea white. Hairs on mesoscutum 40-50 $\mu \mathrm{m}$, whitish, very short velutinous; those on scutellum 200-250 $\mu \mathrm{m}$; those on mesepisternum $300-400 \mu \mathrm{m}$, whitish; propodeal corbicula moderately developed, internal area with short, sparse simple hairs, without anterior fringes; trochanteral floccus imperfect, sparse, whitish; femoral floccus dense; tibial scopal hairs long, simple, whitish. Hairs on metasomal tergum 1 scanty, suberect, white; those on terga 2-4 reratively dense, short, velutinous, whitish; terga 2-4 without white hair bands, only sparse hairs apically; caudal fimbria whitish; sterna 2-5 with long, sparse, whitish subapical fimbriae and short, dense, whitish apical fimbriae.

Structure: Head: HL/HW = 0.92. HW: MsW: MtW $=2.5: 2.2: 2.2$. Vertex round in frontal view, narrow, tessellate with shallow PP. OOD: POD: $\mathrm{OCD}=0.8$ : 0.8: $0.3 . \mathrm{FL} 1=\mathrm{FL} 2+3, \mathrm{FL} 2=\mathrm{FL} 3$ which are as broad as long. Eyes with inner margins paralleled. Facial fovea occupying $1 / 2$ space between eye and lateral ocellus, attaining to a line at lower margins of antennal fossae, FVL $=1.1 \mathrm{~mm}, \mathrm{FVW}=0.25 \mathrm{~mm}$. Supraclypeal area tessellate with shallow PP. Face above antennal fossae with fine longitudinal rugulae and weak interrugal PP, shagreening surface. Facial quadrangle longer than broad (1.7: 1.9). Clypeus strongly convex, surface smooth and shiny below, weakly tessellate above with sparse small PРø20 $\mu \mathrm{m}, \mathrm{IS}=0.5-1$, without longitudinal median impunctate space, $\mathrm{CPL}=1.0 \mathrm{~mm}$. Process of labrum small, triangular. Lower paraocular area smooth and shiny with minute PP, IS $<1$. Malar space linear. Genal area narrower than eye, GW: $\mathrm{EW}=0.5$ : 0.6 , surface weakly tessellate and shiny with minute PP. Mesosoma: Pronotum with obscure lateral suture and without humeral angle, surface very weakly tessellate and shiny with minute PP. Mesoscutum smooth and shiny with distinct, small PPø20 $\mu \mathrm{m}$, IS $<0.5$. Scutellum smooth and shiny with distinct, small PP. Propodeal enclosure finely tessellate all over; dorsal face of propodeum shagreened with roughened PP. Mesepisternum densely tessellate, a little roughened with obscure PP. Vein 1st $m$-cu meeting second submarginal cell at middle of cell.
Metasoma: Metasomal terga smooth and shiny with dense, small PPø20 $\mu \mathrm{m}$, IS=1-2; posterior depressions of terga not well indicated; pygidial plate V-shaped, large, internal area with weak raised triangular area. Sterna 2-5 weakly tessellate and shiny with minute PP.

Specimens examined. [KAZAKHSTAN] 1 female, Polevod, riverside Syrdarya River, S. Kazakhstan Prov., 9. v. 2004 (O. Tadauchi).

Remarks. Similar species is not found in eastern Asia in having the head and thorax with metallic blue reflections, the mesoscutum with very short whitish velutinous hairs, the propodeal enclosure finely tessellate all over, and the metasomal terga 2-4 with relatively dense short whitish velutinous hairs.

Distribution. Uzbekistan, Kazakhstan (new record).

Floral record. Not available.

\section{Acknowledgements}

I am grateful to Prof. V. Kastcheev and Dr. R. Jaschenko of the Zoological Institute, Kazakhstan Academy of Sciences, Almaty, Dr. R. Miyanaga of Shimane Univ., Prof. S. Ikudome of Kagoshima Womens' College, Dr. A. Dawut, Mr. R. Murao and Mr. K. Mitai of Kyushu Univ. for their help in our field survey in Kazakhstan and Kyrgyzstan. I am appreciate to Prof. A. Pesenko of the Zoological Institute, Russian Academy of Sciences, St. Petersburg and Mr. F. Gusenleitner of Oberösterreichischen Landesuseum, Linz for their help in my examining Andrena collection in Russia and Austria, respectively. I also thank Dr. A. Dawut for preparing photos. This is a Contribution from the Entomological Laboratory, Faculty of Agriculture, Kyushu University, Fukuoka (Ser. 6, No. 21). This work was supported by a Grant-in-Aid for Scientific Research (B)(2) from the Japan Society for the Promotion of Science (No. 14405025) (Head Investigator: O. Tadauchi).

\section{References}

Cockerell , T. D. A., 1906a. Descriptions and records of bees 12. Ann. Mag. Nat. Hist., (7) 18: 69-75.

Cockerell , T. D. A., 1906b. New Rocky Mountain bees, and other notes. Can. Ent., 38: 160-166.

Cockerell , T. D. A., 1928. Bees collected in Siberia in 1927. Ann. Mag. Nat. Hist., (10) 1: 345-361.

Cockerell , T. D. A., 1930. Descriptions and records of bees 121. Ann. Mag. Nat. Hist., (10) 5: 108-115.

Eversmann, E., 1852. Fauna Hymenopterologica Volgo-Uralensis. Bull. Soc. Nat. Moscou, 25: 1-137.

Friese, H., 1922. Neue Formen der Bienengattung Andrena (Hym.). Konowia, 1: 209-217.

Gusenleitner, F. \& M. Schwarz, 2000. Angaben zur Morphologie 


\section{GENUS ANDRENA OF KAZAKHSTAN AND KYRGYZSTAN}

einiger von A. Z. Osytshnjuk beschriebener, zumeist asiatischer Andrena-Arten (Hymenoptera: Apidae: Andrenidae). Entomofauna, 21: 381-456.

Gusenleitner, F. \& M. Schwarz, 2001. Zur Morphologie verschiedener von F. Morawitz beschriebener Andrena-Arten (Hymenoptera: Apidae: Andrenidae). Entomofauna, 22: 93-196.

Gusenleitner, F. \& M. Schwarz, 2002. Weltweite Checkliste der Bienengattung Andrena mit Bemerkungen und Ergänzungen zu paläarktischen Arten (Hymenoptera, Apidae, Andreninae, Andrena). Entomofauna, 12, Suppl.: 1-1280.

Lebedev, A. G., 1929. Neue Bienen-Arten aus S.S.S.R. Konowia, 8: 268-272.

Lebedev, A. G., 1932. Einige neue Andrena - Arten aus S.S.S.R. Konowia, 11: 65-73.

Lebedev, A. G., 1933. Einige neue Andrena - Arten aus S.S.S.R. (Schluss). Konowia, 12: 60-65.

Morawitz, F., 1866. Bemerkungen über einige von Prof. Eversmann beschriebene Andrenidae, nebst Zusätzen. Hor. Soc. Ent. Ross., 4: 3-28.

Morawitz, F., 1876. Bienen (Mellifera). II. Andrenidae In Fedtschenko, A. P., Reisen in Turkestan II. Izv. Imp. Obshch. Ljubit. Estest. Antrop. Etnog., 21: 161-303, Taf. 1-3.(In Russian.)

Morawitz, F., 1888. Hymenoptera aculeate nova. Hor. Soc. Ent. Ross., 22: 224-302.

Morawitz, F., 1894. Supplement zur Bienenfauna Turkestans. Hor. Soc. Ent. Ross., 28: 1-87.

Morawitz, F., 1895. Beitrag zur Bienenfauna Turkmeniens. Hor. Soc. Ent. Ross., 29: 1-76.

Osytshnjuk, A. Z., 1977. Bees - Andrenudae (Apoidea, Andrenidae). Fauna Ukraini, 12 (5): 1-328. (In Ukraninean.)

Osytshnjuk, A. Z., 1979. A new species of Andrena F. (Hymenoptera, Apoidea, Andrenidae) from Turkmenistan. Trudy Veses. Ent. Obshch., 61: 174-176. (In Russian.)

Osytshnjuk, A. Z., 1982a. Neue Arten von Bienen der Gattung Andrena (Hymenoptera, Apoidea, Andrenidae) aus Tatschikistan. Vest. Zool., 1982 (2): 32-37. (In Russian.)

Osytshnjuk, A. Z., 1982b. New Middle Asian bee species of the genus Andrena (Hymenoptera, Andrenidae). Vest. Zool., 1982 (5): 25-30. (In Russian.)

Osytshnjuk, A. Z., 1983a. A new subgenus and new species of bees of the genus Andrena F. (Hymenoptera, Andrenidae) from Asiatic part of the USSR. Ent. Obozr., 62: 794-799. (In Russian.)

Osytshnjuk, A. Z., 1983b. Drei neue Arten von Andrena (Hymenoptera, Andrenidae) aus Kasachstan. Vest. Zool., 1983(1): 20-27. (In Russian.)

Osytshnjuk, A. Z., 1984. Four new species of Andrena from Middle Asia. pp. 89-94. In Institut Zoologii im. I. I. Schmalhausen (Hrsg.), Taxonomy and Zoogeography of Insects, Naukova Dunka, Kiev.

Osytshnjuk, A. Z., 1985. Two new Asiatic Andrena species (Hymenoptera, Andrenidae). Vest. Zool., 1985 (3): 19-23. (In Russian.)

Osytshnjuk, A. Z., 1986. New Palaearctic species of the subgenus
Euandrena Hed. (Hymenoptera, Andrenidae, genus Andrena F.). Ent. Obozr., 65: 407-418. (In Russian.)

Osytshnjuk, A. Z., 1993. New Palaearctic species of bees of the subgenus Micrandrena Ashmead (Hymenoptera, Andrenidae, Genus Andrena Fabr.). Ent. Obozr., 72: 401-409, 477. (In Russian.)

Osytshnjuk, A. Z., 1994. New subspecies of Palaearctic Andrena bees (Hymenoptera, Andrenidae). Vest. Zool., 1994 (1): 30-36. (In Russian.)

Osytshnjuk, A. Z., 1995. Andrena. pp. 489-527. In Lehr, P. A. (ed.) Key to the Insects of Russian Far East in Six Volumes. Vol. 4, Neuropteroidea, Mecoptera, Hymenoptera, Part 1. St. Petersburg, Nauka.

Popov, V. V., 1940. Contributions to the knowledge of the Palaearctic species of the genus Andrena F. (Hymenoptera, Apoidea). Trudy Zool. Inst. Leningr., 6: 252-262. (In Russian.)

Popov, V. V., 1949. Subgenus Plastandrena Hedicke and its new representatives (Hym., Apoidea). Ent. Obozr., 30: 389-404. (In Russian.)

Popov, V. V., 1952. The bee fauna (Hymenoptera, Apoidea) of S.W. Turkmenistan and their ecological distribution. Trudy Zool. Inst. Leningr., 10: 61-117. (In Russian.)

Popov, V. V., 1958. On three subgenera of the genus Andrena (Hymenoptera, Andrenidae) . Trudy Vses. Ent. Obshch., 46: 109-161. (In Russian.)

Popov, V. V., 1967. Bees (Hymenoptera, Apoidea) from Central Asia and their spreading by flowering plants. Trudy Zool. Inst. Leningr., 38: 11-329. (In Russian.)

Radoszkowski, O., 1867. Matériaux pour servir à l'étude des insects de la Russie. IV. Notes sur quelques Hyménoptères de la tribu des Apides. Hor. Soc. Ent. Ross., 5: 73-90.

Radoszkowski, O., 1886. Fauna Hyménoptèrologique Transcaspienne. Hor. Soc. Ent. Ross., 20 (1885/1887): 3-56.

Radoszkowski, O., 1893. Faune Hyménoptèrologique Transcaspienne. Hor. Soc. Ent. Ross., 27 (1892-93): 38-81.

Schönitzer, K., 1997. Eine neue Sandbiene aus Zentralasien, die der Andrena (Cordandrena) subsmaragdina Osytshnjuk ähnlich ist: Andrena ledermanni, spec. nov. Spixiana, 20: 309-316.

Tadauchi, O. \& H-1. Xu, 1995. A revision of the subgenus Simandrena of the genus Andrena of eastern Asia with a key to palaearctic species (Hymenoptera, Andrenidae). Esakia, (35): 201-222.

Viereck, H. L., 1916. Preoccupied names in the genus Andrena. Proc. Biol. Soc. Wash., 29: 127.

Viereck, H. L., 1918. Notes on the bee genus Andrena (Hymenoptera). Proc. Biol. Soc. Wash., 31: 59-60.

Warncke, K., 1967. Beitrag zur Klärung paläarktischer Andrena-Arten (Hym. Apidae). Eos, Madr., 43: 171-318.

Xu, H-1. \& O. Tadauchi, 1997. Subgeneric positions and redescriptions of Asian Andrena preserved in the Zoological Institute, Russian Academy of Sciences, St. Petersburg (Hymenoptera, Andrenidae). J. Fac. Agr., Kyushu Univ., 41: 165-178. 